\title{
RADIOCARBON AGE CALIBRATION OF MARINE SAMPLES BACK TO 9000 CAL YR BP
}

\section{MINZE STUIVER*, G W PEARSON**, and TOM BRAZIUNAS*}

\section{INTRODUCTION}

Calibration curves spanning several millennia are now available in this special issue of RADIOCARBON. These curves, nearly all derived from the ${ }^{14} \mathrm{C}$ age determinations of wood samples, are to be used for the age conversion of samples that were formed through use of atmospheric $\mathrm{CO}_{2}$. When samples are formed in reservoirs (eg, lakes and oceans) that differ in specific ${ }^{14} \mathrm{C}$ content from the atmosphere, an age adjustment is needed because a conventional ${ }^{14} \mathrm{C}$ age, although taking into account ${ }^{14} \mathrm{C}$ (and ${ }^{13} \mathrm{C}$ ) fractionation, does not correct for the difference in specific ${ }^{14} \mathrm{C}$ activity (Stuiver \& Polach, 1977). The ${ }^{14} \mathrm{C}$ ages of samples grown in these environments are too old, and a reservoir age correction has to be applied. This phenomenon has been referred to as the reservoir effect (Stuiver \& Polach, 1977).

The reservoir age, or apparent age, $\mathrm{R}(\mathrm{t})$ is here defined as the difference between conventional ${ }^{14} \mathrm{C}$ ages of samples grown contemporaneously in the atmosphere and the other carbon reservoir. $\mathrm{R}(\mathrm{t})$ is not constant $(\mathrm{t}=$ cal age) because the difference in reservoir and atmosphere ${ }^{14} \mathrm{C}$ specific activity is liable to change with changes in reservoir parameters (such as size of the carbon pool, input and output fluxes and exchange with the atmosphere) and atmospheric $\Delta^{14} \mathrm{C}$ values. However, due to the lack of detailed information, a variable reservoir age correction usually cannot be applied, and the user of ${ }^{14} \mathrm{C}$ ages then resorts to the assumption of a constant reservoir age correction $\mathrm{R}^{*}$ (ie, the reservoir ${ }^{14} \mathrm{C}$ specific activity is assumed to parallel atmospheric ${ }^{14} \mathrm{C}$ specific activity at all times). The reservoir age correction $\mathrm{R}^{*}$ is obtained from the conventional ${ }^{14} \mathrm{C}$ age of reservoir samples of either historically known age, or of inferred known age (such as the uppermost portion of lake sediment). This approach is, of course, only a first order approximation. However, even though the resulting reservoir corrected ${ }^{14} \mathrm{C}$ age is not the ultimate in accuracy, the corrected ${ }^{14} \mathrm{C}$ age should be closer to the ${ }^{14} \mathrm{C}$ age of a contemporaneous wood sample than the uncorrected one.

The recent introduction of the dating of mg $\mathrm{C}$ samples through AMS (accelerator mass spectrometry) allows for an improved determination of variable reservoir ages $\mathrm{R}(\mathrm{t})$ in lakes because it is now possible to measure, at different depths, the age differences between 1) those plant macrofossils that were originally utilizing atmospheric ${ }^{14} \mathrm{CO}_{2}, 2$ ) lake carbonate, and 3) gyttja. The first study of this kind has been made for the sediments of a small closed basin of the Lobsingsee, Switzerland (Andrée et al, 1986b). Here the problem of reservoir age corrections can be avoided entirely if a sufficient number of macrofossils formed directly from atmospheric $\mathrm{CO}_{2}$ can be found.

* Department of Geological Sciences and Quaternary Research Center, University of , Seattle 98195

** Palaeoecology Centre, The Queens University of Belfast, Belfast, Northern Ireland
For small carbon reservoirs where the exchange rate with the atmosphere is dominant (eg, a shallow 10 ha lake) the change in specific ${ }^{14} \mathrm{C}$ content may well parallel the observed change in atmospheric ${ }^{14} \mathrm{C}$ content. For other reservoirs, however, appreciable differences are possible. For instance, the top $75 \mathrm{~m}$ of the ocean (well mixed due to wave action, etc) attenuates atmospheric decadal $\Delta^{14} \mathrm{C}$ changes strongly due to its inertia in responding to atmospheric forcing, and the deep ocean lags appreciably in its response to long-term atmospheric ${ }^{14} \mathrm{C}$ change. The idea of a constant reservoir age correction $\mathrm{R} *$ is not tenable in this case.

The reservoir age of marine shells has been determined in the past from the conventional ${ }^{14} \mathrm{C}$ age of shells of known historic age (year AD X), after correcting for fossil fuel $\mathrm{CO}_{2}$-induced ${ }^{14} \mathrm{C}$ age change in the mixed layer of the ocean (Mangerud \& Gulliksen, 1975; Robinson \& Thompson, 1981). This fossil fuel corrected ${ }^{14} \mathrm{C}$ age is then compared with the age of the sample, $i e, 1950-\mathrm{X}$, and the difference is the reservoir or apparen age. This procedure assumes constant atmospheric ${ }^{14} \mathrm{C}$ level, where calendar years and ${ }^{14} \mathrm{C}$ years are interchangeable. Thus, the reservoir age in this instance is the fossil fuel corrected shell ${ }^{14} \mathrm{C}$ age minus the ${ }^{14} \mathrm{C}$ age of a sample formed from atmospheric $\mathrm{CO}_{2}$ in $\mathrm{AD} \mathrm{X}$

Olsson (1980), in addition, discusses the ${ }^{14} \mathrm{C}$ ages of samples formed from atmospheric $\mathrm{CO}_{2}$ of the 19th century, and compares these with the conventional shell ${ }^{14} \mathrm{C}$ ages. The difference again is the apparent or reservoir age. But, as noted by Olsson, "in this discussion, it has been tacitly assumed that the aim is to arrive at a reservoir effect that is not affected by short-term fluctuations of radiocarbon in the atmosphere."

Two avenues of age calibration are possible for a sample formed in a fluctuating ${ }^{14} \mathrm{C}$ environment. One is to derive the variable reservoir age $\mathrm{R}(\mathrm{t})$ in conventional ${ }^{14} \mathrm{C}$ years, apply this correction to obtain a reservoir corrected ${ }^{14} \mathrm{C}$ age, and then use the calibration curves valid for samples formed directly from atmospheric $\mathrm{CO}_{2}$. The other is to produce a separate calibration curve that includes the variability in reservoir ages. Such a curve gives the conventional ${ }^{14} \mathrm{C}$ age minus a $\Delta \mathrm{R}$ number (explained later on) $v$ s the cal $\mathrm{BP}(\mathrm{cal} \mathrm{AD} / \mathrm{BC})$ age. We here follow the latter approach for marine samples.

A box-diffusion model as described by Oeschger et al (1975) was used to simulate global carbon exchange. We attribute the observed atmospheric $\Delta^{14} \mathrm{C}$ variability of the last $9000 \mathrm{yr}$ to solar (heliomagnetic) and geomagnetic modulation of the cosmic ray flux (Stuiver \& Quay, 1980; Sternberg \& Damon, 1983), and consider model parameter change induced by oceanic (climate) change to be negligible over this time interval (Andrée et $a l, 1986 \mathrm{a})$. The observed atmospheric $\Delta^{14} \mathrm{C}$ record is used to calculate the ${ }^{14} \mathrm{C}$ content of the mixed layer (top $75 \mathrm{~m}$ ) of the model ocean, and the model mixed layer ${ }^{14} \mathrm{C}$ ages are plotted $v s$ cal $\mathrm{AD} / \mathrm{BC}$ (cal $\mathrm{BP}$ ) ages. The calibration curves are different from those given elsewhere in this issue because the ${ }^{14} \mathrm{C}$ ages are not directly measured but calculated from the atmospheric record 
through carbon reservoir modeling. The curves therefore not only reflect the original measuring uncertainty in the wood $\Delta^{14} \mathrm{C}$ values that constitute the model input, but also uncertainties in model parameters.

\section{THE GLOBAL CARBON MODEL}

The atmospheric $\Delta^{14} \mathrm{C}$ data used as input for the model span the $\mathrm{AD}$ 1950-7746 BC interval. A composite data set (Fig 1) was derived by combining the data of Stuiver and Pearson (1986) for the AD 1950-500 BC interval, of Pearson and Stuiver (1986) for 500-2490 BC, of Pearson et al (1986) for 2500-5210 BC, of Linick, Suess and Becker (1985) for 5219$5346 \mathrm{BC}$ and 5818-5882 BC, of Stuiver et al (1986) for 5685-5815 BC, 6475-6552 BC, and 6574-7198 BC, of Kromer et al (1986) for 5908-6200 $\mathrm{BC}, 6279-6469 \mathrm{BC}$, and 7206-7746 BC, and of Linick et al (1986) for 5355$5675 \mathrm{BC}$ and $6205-6275 \mathrm{BC}$. The Figure 1 data represent average $\Delta^{14} \mathrm{C}$ values of 20 -yr samples back to $5220 \mathrm{BC}$, and of a mixture of intervals (single yr to up to $20 \mathrm{yr}$ ) prior to that.

Detailed atmospheric $\Delta^{14} \mathrm{C}$ on a decadal scale is given in Figure 2 for the last 4500 yr (Stuiver \& Becker, 1986).

For the carbon reservoir modeling, we constructed a curve with bidecadal coverage for the entire AD 1950-7740 BC interval. The initial equilibrium conditions of the model were set at an atmospheric $\Delta^{14} \mathrm{C}$ value of $+90 \%$ (Stuiver et al, 1986). An important parameter of the box-diffusion model (see also Stuiver \& Quay, 1981) is the atmospheric $\mathrm{CO}_{2}$ concentration which is fixed at 280ppm (Neftel et al,1985; Stuiver, Burk \& Quay, 1984). Oceanic C concentration is set at 2.31 moles $/ \mathrm{m}^{3}$ (Takahashi, Broecker \& Bainbridge, 1981). The biosphere is set at a constant 1900 Gigatons C (Olson, Pfuderer \& Chan, 1978). The biosphere is divided into two reservoirs with residence times of $2.7 \mathrm{yr}$ and $80 \mathrm{yr}$ (Emanuel et al, 1984). The reservoir with fast turnover contains $10.6 \%$ of the total biomass, the other $89.4 \%$ (Emanuel et al, 1984). Gas exchange rate $\mathrm{F}$ is set at 19 moles $/ \mathrm{m}^{2} \mathrm{yr}$ in order to yield a nearly $50 \% \Delta^{14} \mathrm{C}$ difference between the atmosphere and mixed layer in the year 1830 (the last bi-decadal midpoint without fossil fuel $\mathrm{CO}_{2}$ influence). To generate a $40 \%$ difference between the atmospheric and mixed layer $\Delta^{14} \mathrm{C}, \mathrm{F}$ has to be adjusted to 24 moles/ $\mathrm{m}^{2} \mathrm{yr}$.

A vertical diffusion coefficient $\mathrm{K}_{\mathrm{z}}$ of $1.26 \mathrm{~cm}^{2} / \mathrm{sec}$ yields a deep ocean $\Delta^{14} \mathrm{C}$ value of $-190 \%$ in 1850 , in agreement with GEOSECS measurements (Stuiver, Quay \& Östlund, 1983).

\section{MODEL RESULTS}

The model input is the post-7750 $\mathrm{BC}$ atmospheric $\Delta^{14} \mathrm{C}$ record, of which the post $-7200 \mathrm{BC}$ portion is given in the top curve of Figure 3 . The $\Delta^{14} \mathrm{C}$ values of the $550 \mathrm{yr}$ preceding $7200 \mathrm{BC}$ (Fig 1) were used for a proper startup of the model.

Model-derived mixed layer $\Delta^{14} \mathrm{C}$ values $\left(\mathrm{F}=19\right.$ moles $/ \mathrm{m}^{2} \mathrm{yr}, \mathrm{K}=$ $1.26 \mathrm{~cm}^{2} / \mathrm{sec}$, to yield a mixed layer $\Delta^{14} \mathrm{C}=-49.7 \%(\mathrm{R}=409 \mathrm{yr})$ at $\mathrm{AD}$ $1830)$ are given in the middle curve. Relative to the atmosphere, there is a substantial attenuation of the higher $\Delta^{14} \mathrm{C}$ frequencies in the mixed layer. For the deep ocean (bottom curve) only a long-term trend remains.

To determine the sensitivity of the model results to the choice of $\mathrm{F}$ and $\mathrm{K}_{z}$, we also generated mixed layer $\Delta^{14} \mathrm{C}$ values with model parameters set at $\mathrm{F}=24 \mathrm{moles} / \mathrm{m}^{2} \mathrm{yr}, \mathrm{K}_{\mathrm{z}}=1.26 \mathrm{~cm}^{2} / \mathrm{sec}$, to yield a mixed layer $\Delta^{14} \mathrm{C}=$ $-40.4 \%(\mathrm{R}=331 \mathrm{yr})$ at $\mathrm{AD} 1830$. The difference between the $\mathrm{F}=19$ and $\mathrm{F}=24 \mathrm{moles} / \mathrm{m}^{2}$ yr model outputs of mixed layer $\Delta^{14} \mathrm{C}$ values and ${ }^{14} \mathrm{C}$ ages are given in Figure 4. Evidently the calibration curve is relatively insensitive to $\mathrm{F}$ because the model-calculated mixed layer ages, after normalization on the same baseline, differ by up to $16{ }^{14} \mathrm{C}$ years.

Eddy diffusivity is faster in the upper portion of the ocean than in the lower part (Stuiver, 1980). We compared the model-generated mixed layer ${ }^{14} \mathrm{C}$ ages for $\mathrm{K}_{7}$ values of $1.26 \mathrm{~cm}^{2} / \mathrm{sec}$ and $2.2 \mathrm{~cm}^{2} / \mathrm{sec}$, with $\mathrm{R}$ set at $409 \mathrm{yr}$ in $\mathrm{AD} 1830$ in both cases. The faster diffusivity was accompanied by an increased exchange coefficient $\mathrm{F}$ of 20 moles $/ \mathrm{m}^{2} \mathrm{yr}$. The resulting model outputs of mixed layer ${ }^{14} \mathrm{C}$ ages differed by a fraction of a decade for the long term (millennia), as well as the shorter term (century) type oscillations. Thus, the fine structure of the model mixed layer curves is not sensitive to assumed $\mathrm{K}_{\mathrm{z}}$ values.

Figure 5 gives the conventional ${ }^{14} \mathrm{C}$ ages of the atmosphere, mixed layer of the ocean, and the deep ocean. The differences in basic features of the atmospheric and marine calibration curves are caused by the strong attenuation in the oceans of the higher frequency $\Delta^{14} \mathrm{C}$ perturbation. This leads to the variable $\mathrm{R}(\mathrm{t})$. With the traditional method of correcting marine ${ }^{14} \mathrm{C}$ ages one would deduct a fixed reservoir age $\mathrm{R}^{*}$ (derived for one year only) from the Figure 5 results and use it for all ages. Two examples of this approach are given in Figures 6 and 7 where fixed reservoir ages of $409 \mathrm{yr}$ and $1684 \mathrm{yr}$ are deducted from, respectively, the mixed layer and deep ocean ${ }^{14} \mathrm{C}$ ages. The deducted reservoir ages are those calculated for the year 1830 . Whereas the fixed reservoir age concept indeed gives calibration curves resembling the atmospheric one for the 4300-5000 BC interval (Fig 6 ), appreciable differences are found for the 200-900 BC interval (Fig 7). This is due partially to the perturbation in atmospheric $\Delta^{14} \mathrm{C}$ between 400 and $750 \mathrm{BC}$ which results in the horizontal portion of the Figure 7 atmospheric calibration curve. This perturbation is much smaller in the mixed layer, and absent in the deep ocean (Fig 7). Similarly, the lag in deep ocean response to the long-term post $5000 \mathrm{BC}$ atmospheric $\Delta^{14} \mathrm{C}$ decline results in the lower curve offset in Figure 7.

Atmospheric $\Delta^{14} \mathrm{C}$ changes in our model are caused by production rate changes. The atmospheric $\Delta^{14} \mathrm{C}$ changes in turn influence the oceans. A reverse scenario in which changes in ocean circulation lead to atmospheric $\Delta^{14} \mathrm{C}$ changes is contradicted by the work of Andrée et al $(1986 \mathrm{a})$ on the ${ }^{14} \mathrm{C}$ age differences of the mixed layer and the deep ocean. These age differences were derived from the ${ }^{14} \mathrm{C}$ ages of planktonic and benthic marine organisms in two sediment cores of the South China Sea (Fig 8). As discussed by Andrée et al (1986a), a drastic post 6000 BP speed-up in ocean circulation is needed if the oceans would be the primary cause of the long- 
term change (Fig 1) in atmospheric $\Delta^{14} \mathrm{C}$ values. For this scenario a much lower rate of ocean mixing is needed in the early Holocene which would generate ${ }^{14} \mathrm{C}$ age differences twice as large as currently found between mixed layer and deep ocean (Andrée et al, 1986a). As this is not the case (Fig 8), our first order assumption of constant reservoir parameters is justified. It should be noted, however, that even with a fixed mode of ocean circulation, changes of up to $200 \mathrm{yr}$ are possible in the mixed layer-deep sea Holocene ${ }^{14} \mathrm{C}$ age differences (Fig 8).

The variable reservoir ages $R(t)$ of the mixed layer and deep ocean deduced from Figure 5 are given in Figure 9A. The atmospheric $\Delta^{14} \mathrm{C}$ lowering associated with fossil fuel combustion decreases the reservoir age of the mixed layer and deep ocean by about, respectively, $100 \mathrm{yr}$ and $170 \mathrm{yr}$ between AD 1850 and 1950 (Fig 9B).

\section{RADIOCARBON AGE CALIBRATION AND $\triangle$ R DETERMINATION}

The question arises how a user provided with a conventional ${ }^{14} \mathrm{C}$ age of a sample from a certain part of the ocean should use the calibration curves that are calculated for the world oceans. After proper correction for isotope fractionation (Stuiver \& Polach, 1977), the conventional ${ }^{14} \mathrm{C}$ ages of marine shells are generally too old. The age anomaly (reservoir age) is 200 to $400 \mathrm{yr}$ for the mixed layer of the world oceans, but may be larger in areas of upwelling (up to $1300 \mathrm{yr}$, Stuiver \& Braziunas, 1985)

Our calibration curves depict the relationship between cal AD/BC (cal BP) ages and conventional (Stuiver \& Polach, 1977) ${ }^{14} \mathrm{C}$ ages. Those ${ }^{14} \mathrm{C}$ ages are corrected for isotope fractionation, but not for any reservoir deficiency. The model mixed layer and deep ocean reservoir ages average, respectively, $373 \mathrm{yr}$ and $1554 \mathrm{yr}$ over the last $9000 \mathrm{yr}$. These averages resul from our choice of specific model parameters and do not reflect local variations in the ocean reservoir ages.

To accommodate local effects, the model ocean can be matched with regional parts of the world ocean by assuming a parallel $\Delta^{14} \mathrm{C}$ response, $i e$, we assume as a first approximation identical time-dependent response of the regional and world ocean to atmospheric forcing. Further refinement would be possible if each region could be modeled separately. However, we have to work at present with the above approximation.

The reader of the previous sections will have noticed the time-dependent character of the reservoir age $\mathrm{R}(\mathrm{t})$ of the mixed layer of the ocean. The reservoir age, or the conventional ${ }^{14} \mathrm{C}$ age difference between samples formed contemporaneously in the mixed layer and the atmosphere, is timedependent because the oceanic $\Delta^{14} \mathrm{C}$ response to atmospheric $\Delta^{14} \mathrm{C}$ forcing differs from the atmospheric signal. However, an approximately parallel response to atmospheric forcing of a regional part of the ocean and the world ocean results in a constant difference $(\Delta \mathrm{R})$ in reservoir age of the two. Thus, although reservoir ages are time-dependent, $\Delta \mathrm{R}$, as a first approximation, is not

The difference $\Delta \mathrm{R}$ in reservoir age of the regional part of the ocean from which the users sample is derived, and the reservoir age of our model ocean, is determined through the use of Figure 10A. The user needs infor- mation on reservoir ages, $i e$, a ${ }^{14} \mathrm{C}$ age $\mathrm{P}$ should be available for a historic (year AD X) sample collected from the same reservoir from which his/her sample is derived. The user has to derive from Fig 10A the model mixed layer (or deep ocean) ${ }^{14} \mathrm{C}$ age $\mathrm{Q}$ for year $\mathrm{AD} \mathrm{X}$. The correction factor to be used for the sample ${ }^{14} \mathrm{C}$ age in the calibration Figures 11 and 12 is then $\Delta \mathrm{R}=\mathrm{P}-\mathrm{Q}$.

In case the user lacks information on ${ }^{14} \mathrm{C}$ ages of historic samples he/ she can assume the sample comes from an environment similar to the model world ocean. The Figure 11 and 12 calibration curves (with $\Delta \mathrm{R}=0$ ) can then be used directly.

Our calculations neglect hemispheric reservoir differences that cause ${ }^{14} \mathrm{C}$ ages of atmospheric samples of the Southern Hemisphere to be ca 30 years older than those of the Northern Hemisphere. Hemispheric differences will be taken into account in a model currently being developed by one of us (T Braziunas).

Suggested $\Delta \mathrm{R}$ values for various oceanic regions are plotted in Figure 10B. These weighted mean $\Delta \mathrm{R}$ values were derived from ${ }^{14} \mathrm{C}$ ages listed in Table 1, which also gives the sample groupings from which the average $\Delta R$ values were derived. Except for a few instances, Table 1 contains only shell sample dates.

The standard deviations given with $\Delta \mathrm{R}$ in Table 1 were derived from the errors reported with the ${ }^{94} \mathrm{C}$ ages. The ${ }^{14} \mathrm{C}$ age groupings also can be viewed as a data set from which the standard deviation ("scatter" sigma) in the unweighted mean can be calculated. These "scatter" sigmas in the unweighted mean are given in Table 1

The largest of each set of sigmas was used for the + value plotted in Figure $10 \mathrm{~B}$. In view of the much debated under-reporting of ${ }^{14} \mathrm{C}$ age errors, it was gratifying to see that the scatter sigma was, on average, only 1.1 times the ${ }^{14} \mathrm{C}$ age sigma. From this we conclude 1) the additional uncertainty in $\Delta \mathrm{R}$ introduced by non-uniform ${ }^{14} \mathrm{C}$ content of the regional ocean reservoirs is small, and 2) the age errors given for the Table 1 shell samples are realistic estimates of the measurement precision.

The uncertainty in the age conversion process depends on the extent to which a particular sample's environment resembles the average model world ocean, and on the degree to which the model simulates the reality. It is not possible to give these uncertainties as standard deviations, and the calibration curves therefore lack an uncertainty band.

When converting a conventional ${ }^{14} \mathrm{C}$ age into cal $\mathrm{AD} / \mathrm{BC}$ (or cal $\mathrm{BP}$ ) age, the standard deviation in the sample age determination $\sigma_{\mathrm{s}}$ should be taken into account. There will be an additional error in either the determined or the assumed reservoir age difference $\Delta \mathrm{R}$. As noted, $\Delta \mathrm{R}=\mathrm{P}-\mathrm{Q}$ where $\mathrm{P}$ is the conventional ${ }^{14} \mathrm{C}$ age of an historic sample, and $\mathrm{Q}$ the model-calculated conventional ${ }^{14} \mathrm{C}$ age of a sample of the same historic age. The $\Delta \mathrm{R}$ error $\left(\sigma_{\mathrm{R}}\right)$ depends on the error in $P$, as well as $Q$. We do not have a standard error for the model-calculated $Q$ value. Only a lower limit can be given for $\sigma_{\mathrm{R}}$ by substituting the error in the ${ }^{14} \mathrm{C}$ age determination $\mathrm{P}$. This error is listed in Table 1 as a "minimum estimate" for $\sigma_{\mathrm{R}}$.

The $\sigma_{\mathrm{R}}$ should be combined with $\sigma_{\mathrm{s}}$ according to $\sigma_{\text {total }}=\sqrt{\sigma_{\mathrm{s}}^{2}+\sigma_{\mathrm{R}}^{2}}$. The 
$\left({ }^{14} \mathrm{C}\right.$ age $\left.-\Delta \mathrm{R}\right) \pm \sigma_{\text {total }}$, after conversion, determines a minimum range in calibrated ages.

Marine and "atmospheric" samples with identical ${ }^{14} \mathrm{C}$ ages and standard deviations will differ in calibrated age, as well as in the range in calibrated ages. The cal range will usually be larger for the marine sample due to the incorporation of the standard deviation $\sigma_{\mathrm{R}}$ in the reservoir age difference $\Delta R$. The issue of multiple intercepts, however, is much less important for marine samples because the calibration curves (Figs 11, 12) are much less wiggley than the corresponding atmospheric ones (eg, Stuiver \& Pearson, 1986)

\section{ACKNOWLEDGMENTS}

${ }^{14} \mathrm{C}$ research of the Quaternary Isotope Laboratory is supported through National Science Foundation grant ATM-8318665 of the Climate Dynamics Program and EAR-8115994 of the Environmental Geosciences Program. The work of the Belfast laboratory was supported through a SERC grant to the Queens University. P D Quay generously provided the basic carbon reservoir computer model from which, after modifications, the calculations were made.

\section{REFERENCES}

Andrée, M, Oeschger, H, Broecker, W S, Beavean, N, Klas, M, Mix, A, Bonani, G, Hofmann, $\mathrm{H}$ J, Suter, M, Woelfli, W and Peng, T H, 1986a, Limits on the ventilation rate for the deep ocean over the last 12,000 years: Climate Dynamics, v 1, in press.

Andrée, M, Oeschger, H, Siegenthaler, U, Riesen, T, Moell, M, Amman, B and Tobolski, K, $1986 \mathrm{~b},{ }^{14} \mathrm{C}$ dating by AMS of plant macrofossils in lake sediment, in Stuiver, $\mathrm{M}$ and Kra, R S, eds, Internatl ${ }^{14} \mathrm{C}$ conf, 12th, Proc: Radiocarbon, v 28, no. 2A, p 411-41

Berger, R, Taylor, R E and Libby, W F, 1966, Radiocarbon content of marine shells from the California and Mexican west coast: Science, v 153, p 864-866.

Broecker, W S and Olson, E A, 1959, Lamont radiocarbon measurements VI: Am Jour Sci Radiocarbon Supp, v 1, p 111-132.

Broecker, W S and Olson, E A, 1961, Lamont radiocarbon measurements VII: Radiocarbon, v 3 , p $176-204$

Druffel, E M and Linick, T W, 1978, Radiocarbon in annual coral rings of Florida: Geophys Research Letters, v 5, p 913-916.

Emanuel, W R, Killough, G G, Post, W M and Shugart, H H, 1984, Modeling terrestrial ecosystems in the global carbon cycle with shifts in carbon storage capacity by land-use change: Ecology, v 65, no. 3, p 970-983

Gillespie, R and Polach, H A, 1979, The suitability of marine shells for radiocarbon dating of Australian prehistory, in Berger, $\mathrm{R}$ and Suess, $\mathrm{HE}$, eds, Radiocarbon dating, Internat ${ }^{1{ }^{4} \mathrm{C}}$ conf, 9th, Proc: Berkeley, Univ California Press, p 404-421.

Hakansson, S, 1969, University of Lund radiocarbon dates II: Radiocarbon, v 11, no. 2, p $430-450$.

534-552 1970, University of Lund radiocarbon dates III: Radiocarbon, v 12, no. 2, p $534-552$.

493-513. 1973, University of Lund radiocarbon dates VI: Radiocarbon, v 15, no. 3, p

Kromer, B, Rhein, M, Bruns, M, Schoch-Fischer, H, Münnich, KO, Stuiver, M and Becker, B, 1986, Radiocarbon calibration data for the 6 th to the 8 th millenium BC, in Stuiver, $M$ and $\mathrm{Kra}$, R S, eds, Internatl ${ }^{14} \mathrm{C}$ conf, 12 th, Proc: Radiocarbon, this issue.

Linick, T W, Long, A, Damon, P E and Ferguson, C W, 1986, High-precision radiocarbon dating of bristlecone pine from 6550 to $5350 \mathrm{BC}$, in Stuiver, M and Kra, R S, eds, Internatl ${ }^{14} \mathrm{C}$ conf, $12 \mathrm{th}$, Proc: Radiocarbon, this issue.

Linick, T W, Suess, H E and Becker, B, 1985, La Jolla measurements of radiocarbon in South German Oak tree-ring chronologies: Radiocarbon, v 27, no. 1, p 20-32.
Mangerud, J, 1972, Radiocarbon dating of marine shells, including a discussion of apparen age of recent shells from Norway: Boreas, v 1, p 143-172.

Mangerud, J and Gulliksen, S, 1975, Apparent radiocarbon ages of Recent marine shells from Norway, Spitsbergen, and Arctic Canada: Quaternary Kesearch, v 5, p 263-273.

Neftel, A, Moore, E, Oeschger, $\mathrm{H}$ and Stauffer, B, 1985, Evidence from polar ice cores for the increase in atmospheric $\mathrm{CO}_{2}$ in the past two centuries: Nature, v 315, p 45-47.

Oeschger, H, Siegenthaler, U, Schotterer, U and Gugelmann, A, 1975, A box diffusion model to study the carbon dioxide exchange in nature: Tellus, v 27, p 168-192.

Olson, J S, Pfuderer, H A and Chan, Y H, 1978, Changes in the global carbon cycle and the biosphere: Environmental Sci Div, Oak Ridge Natl Lab Pub No. 1050

Olsson, I U, 1960, Uppsala natural radiocarbon measurements II: Am Jour Sci Radiocarbon Supp, v 2, p $112-128$.

- 1980, Content of ${ }^{14} \mathrm{C}$ in marine mammals from northern Europe, in Stuiver, $\mathrm{M}$ and Kra, R S, eds, Internatl ${ }^{14} \mathrm{C}$ conf, 10th, Proc: Radiocarbon, v 22, no. 3, p 662-675.

Olsson, I U, El-Gammal, S and Goksu, Y, 1969, Uppsala natural radiocarbon measurement IX: Radiocarbon, v 11, no. 2, p 515-544.

Pearson, G W, Pilcher, J R, Baillie, M G L, Corbett, D M and Qua, F, 1986, High-precision ${ }^{14} \mathrm{C}$ measurement of Irish Oaks to show the natural ${ }^{14} \mathrm{C}$ variations from $5210 \mathrm{BC}$ to $\mathrm{AD} 1840$, in Stuiver, $\mathrm{M}$ and Kra, R S, eds, Internatl ${ }^{14} \mathrm{C}$ conf, 12 th, Proc: Radiocarbon, this issue.

Pearson, G W and Stuiver, M, 1986, High-precision calibration of the radiocarbon time scale $500-2500 \mathrm{BC}$, in Stuiver, $\mathrm{M}$ and Kra, R S, eds, Internat ${ }^{14} \mathrm{C}$ conf, 12 th, Proc: Radiocar-

Rafter, T A, Jansen, H S, Lockerbie, L and Trotter, M M, 1972, New Zealand radiocarbon reference standards, in Rafter, T A and Grant-Taylor, T, eds, Internatl conf on ${ }^{14} \mathrm{C}$ dating, 8th, Proc: Wellington, Royal Soc New Zealand, v 2, p H29-H79.

Robinson, S W and Thompson, G, 1981, Radiocarbon corrections for marine shell dates with application to southern Pacific Northwest Coast prehistory: Syesis, v 14, p 45-57.

Sternberg, R S and Damon, P E, 1983, Atmospheric radiocarbon: implications for the geomagnetic dipole moment, in Stuiver, $\mathrm{M}$ and Kra, R S, eds, Internatl ${ }^{14} \mathrm{C}$ conf, 11 th, Proc Radiocarbon, v 25, no. 2, p 239-248.

Stuiver, M, 1980, ${ }^{14} \mathrm{C}$ distribution in the Atlantic Ocean: Jour Geophys Research, v 85, p

2711-2718.
Stuiver, $\mathrm{M}$ and Becker, B, 1986, A decadal high-precision calibration curve, in Stuiver, $M$ and Kra, R S, eds, Internatl ${ }^{14} \mathrm{C}$ conf, 12 th, Proc: Radiocarbon, this issue.

Stuiver, $M$ and Braziunas, T F, 1985, Compilation of isotopic dates from Antarctica: Radiocarbon, v 27, no. 2A, p $117-304$.

Stuiver, $\mathrm{M}$ and Pearson, G W, 1986, High-precision calibration of the radiocarbon time scale $\mathrm{AD} 1950-500 \mathrm{BC}$, in Stuiver, $\mathrm{M}$ and Kra, R S, eds, Internatl ${ }^{14} \mathrm{C}$ conf, 12th, Proc: Radiocarbon, this issue.

Stuiver, M and Polach, H A, 1977, Discussion: Reporting of ${ }^{14} \mathrm{C}$ data: Radiocarbon, v 19, no 3 , p 355-363.

Stuiver, $\mathrm{M}$ and Quay, PD, 1980, Changes in atmospheric carbon-14 attributed to a variable sun: Science, v 207, p 11-19.

- 1981, Atmospheric ${ }^{i 4} \mathrm{C}$ changes resulting from fossil fuel $\mathrm{CO}_{2}$ release and cosmic ray flux variability: Earth Planetary Sci Letters, v 53, p 349-362.

Stuiver, M, Burk, R L and Quay, P D, $1984,{ }^{13} \mathrm{C} /{ }^{12} \mathrm{C}$ ratios in tree rings and the transfer of biospheric carbon to the atmosphere: Jour Geophys Research, v 89, p 11731-11748.

Stuiver, M, Denton, G H, Hughes, T J and Fastook, J L, 1981, History of last glaciation: A working hypothesis, in Denton, $\mathrm{G} \mathrm{H}$ and Hughes, $\mathrm{T}$ J, eds, The last great ice sheets: New York, John Wiley \& Sons, p 319-440.

Stuiver, M, Kromer, B, Becker, $\mathrm{H}$ and Ferguson, C W, 1986, Radiocarbon age calibration back to $13,300 \mathrm{yr}$ BP and the ${ }^{14} \mathrm{C}$ age matching of the German Oak and US Bristlecone Pine chronologies, in Stuiver, M and Kra, R S, eds, Internatl ${ }^{14} \mathrm{C}$ conf, 12 th, Proc: Radiocarbon, this issue.

Stuiver, M, Quay, PD and Östlund, H G, 1983, Abyssal water carbon-14 distribution and the age of the world oceans: Science, $v 219$, p 849-851.

Takahashi, T, Broecker, W S and Bainbridge, A E, 1981, The alkalinity and total carbon dioxide concentration in the world oceans, in Bolin, B, ed, Carbon cycle modelling: SCOPE 16: New York, John Wiley \& Sons, p 271-286.

Taylor, R E and Berger, R, 1967 , Radiocarbon content of marine shells from the Pacific coasts of Central and South America: Science, v 158, p 1180-1182.

Washburn, A L and Stuiver, M, 1962, Radiocarbon-dated postglacial delevelling in north-east Greenland and its implications: Arctic, v 15, p 66-73. 


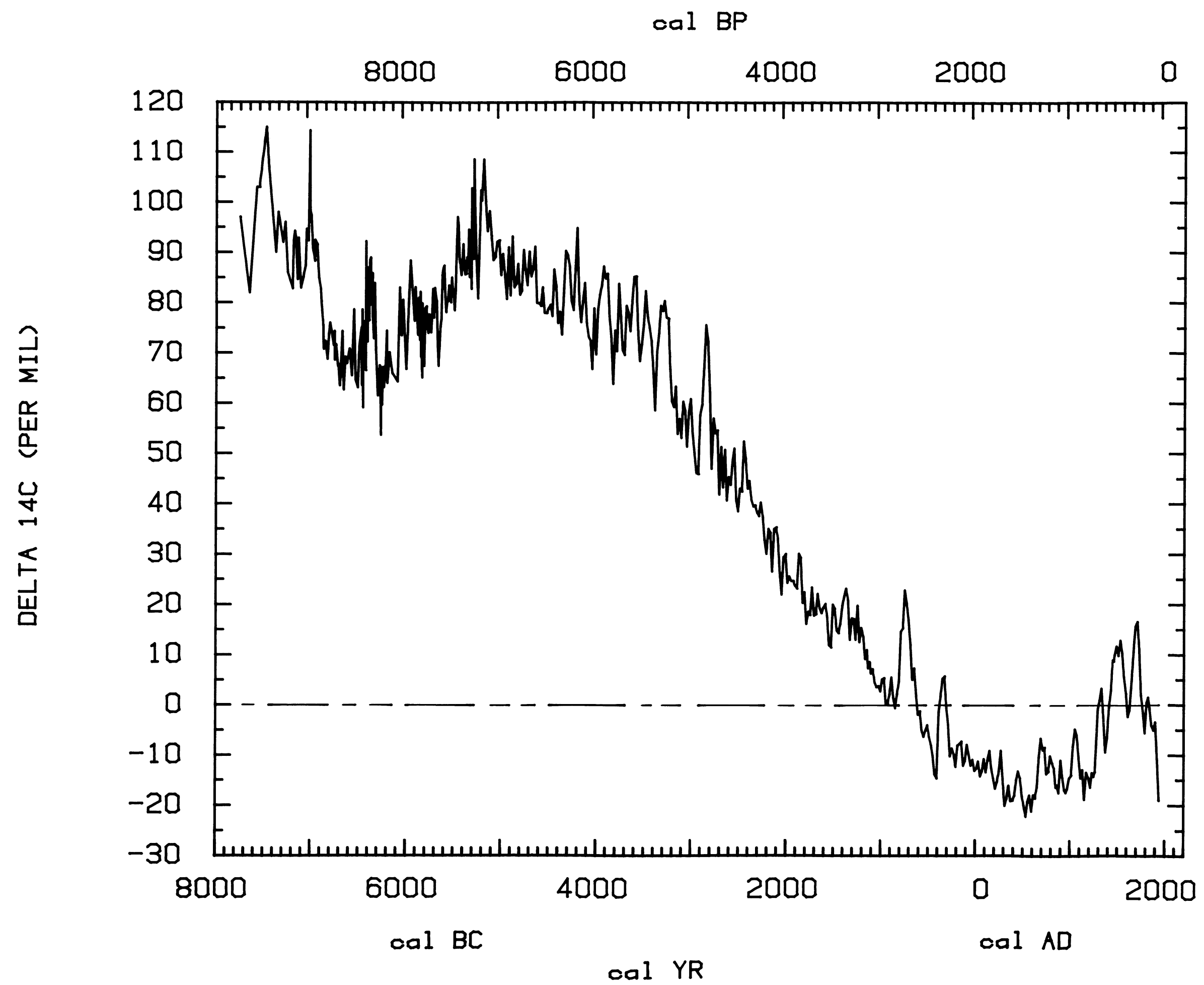

Fig 1. Atmospheric $\Delta^{14} \mathrm{C}$ vs age. Compiled from data sources given in the text. 


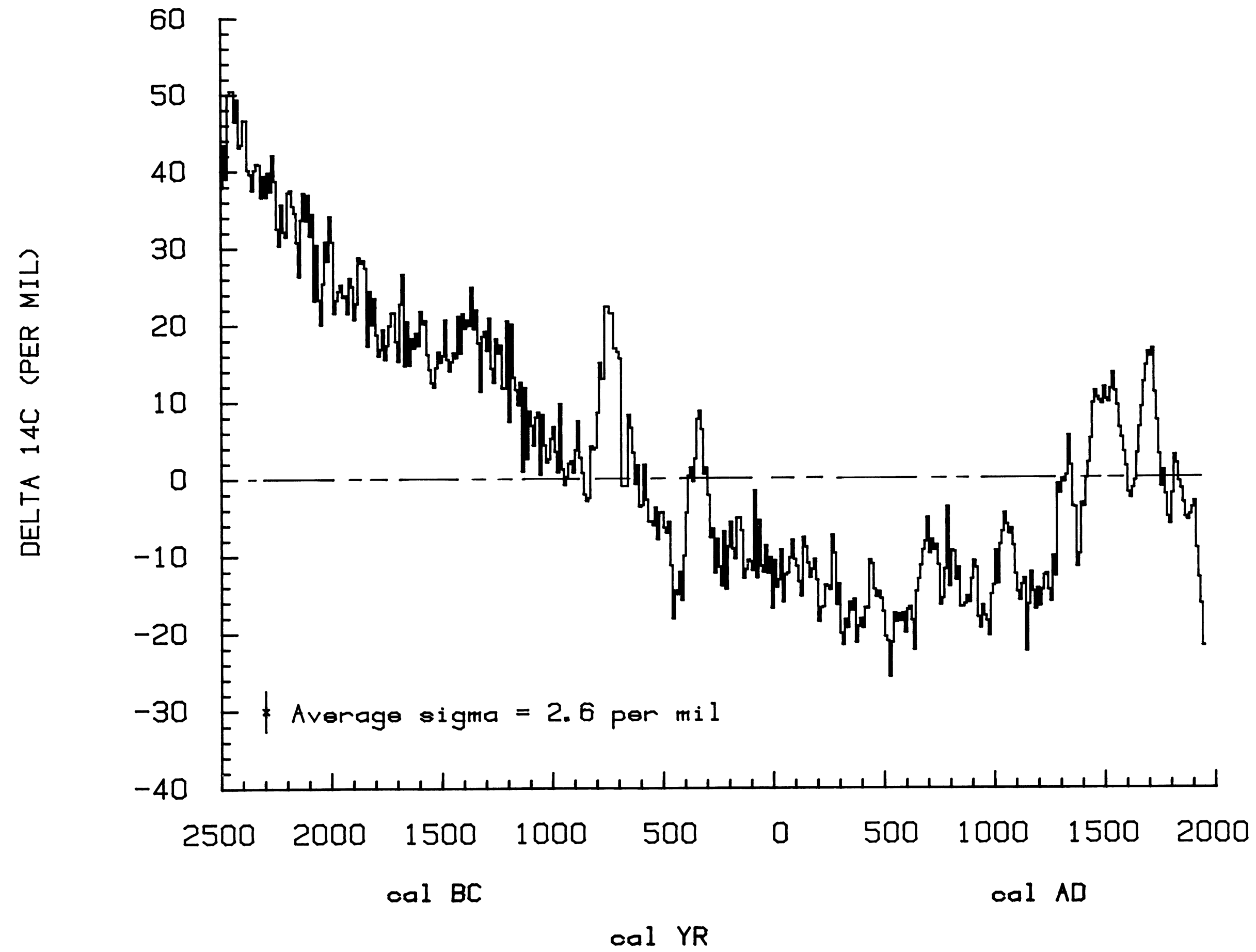

Fig 2. Atmospheric $\Delta^{14} \mathrm{C}$ of the past $4 \frac{1}{1} / 2$ millennia for each decade (Stuiver \& Becker, 1986). The average standard deviation of the decadal measurements is $2.6 \%$. 


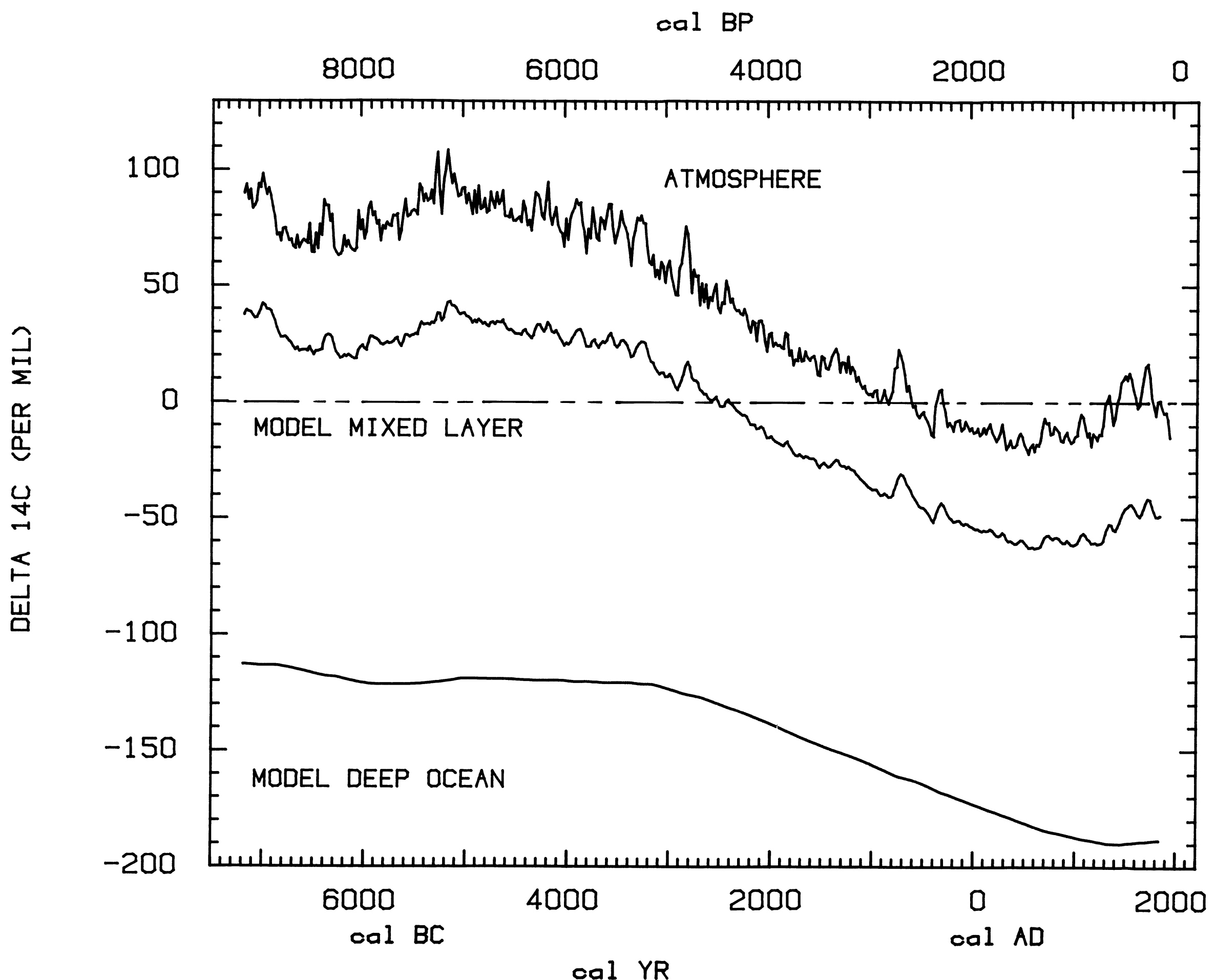

Fig 3. Atmospheric $\Delta^{14} \mathrm{C}$ (bi-decadal values) as used for the model calculations and calculated mixed layer and deep ocean $\Delta^{14} \mathrm{C}$ values. 

cal BP

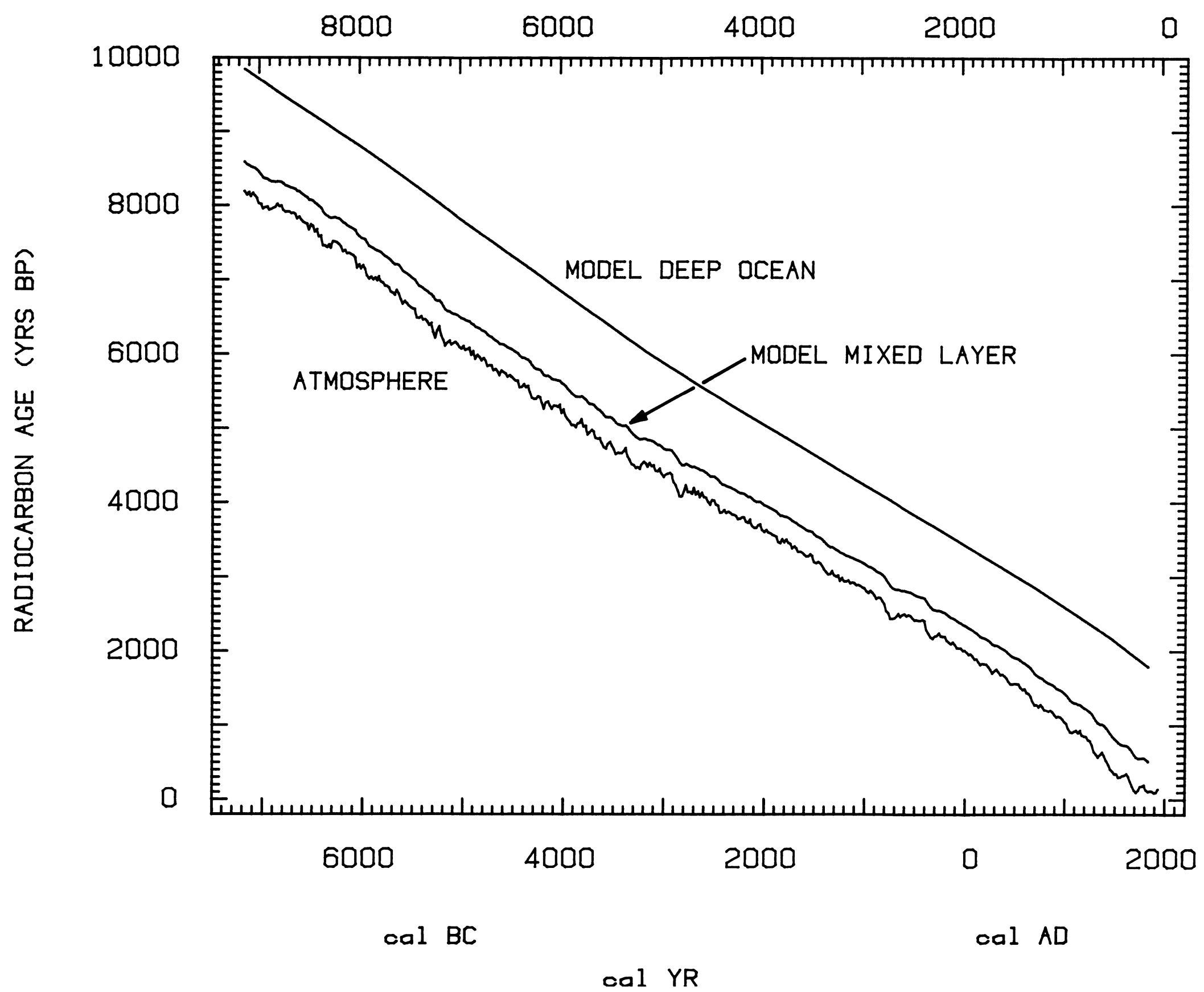

Fig $5 .{ }^{14} \mathrm{C}$ ages of the atmosphere (bi-decadal values) and calculated conventional ${ }^{14} \mathrm{C}$ ages of the mixed layer and deep ocean. 


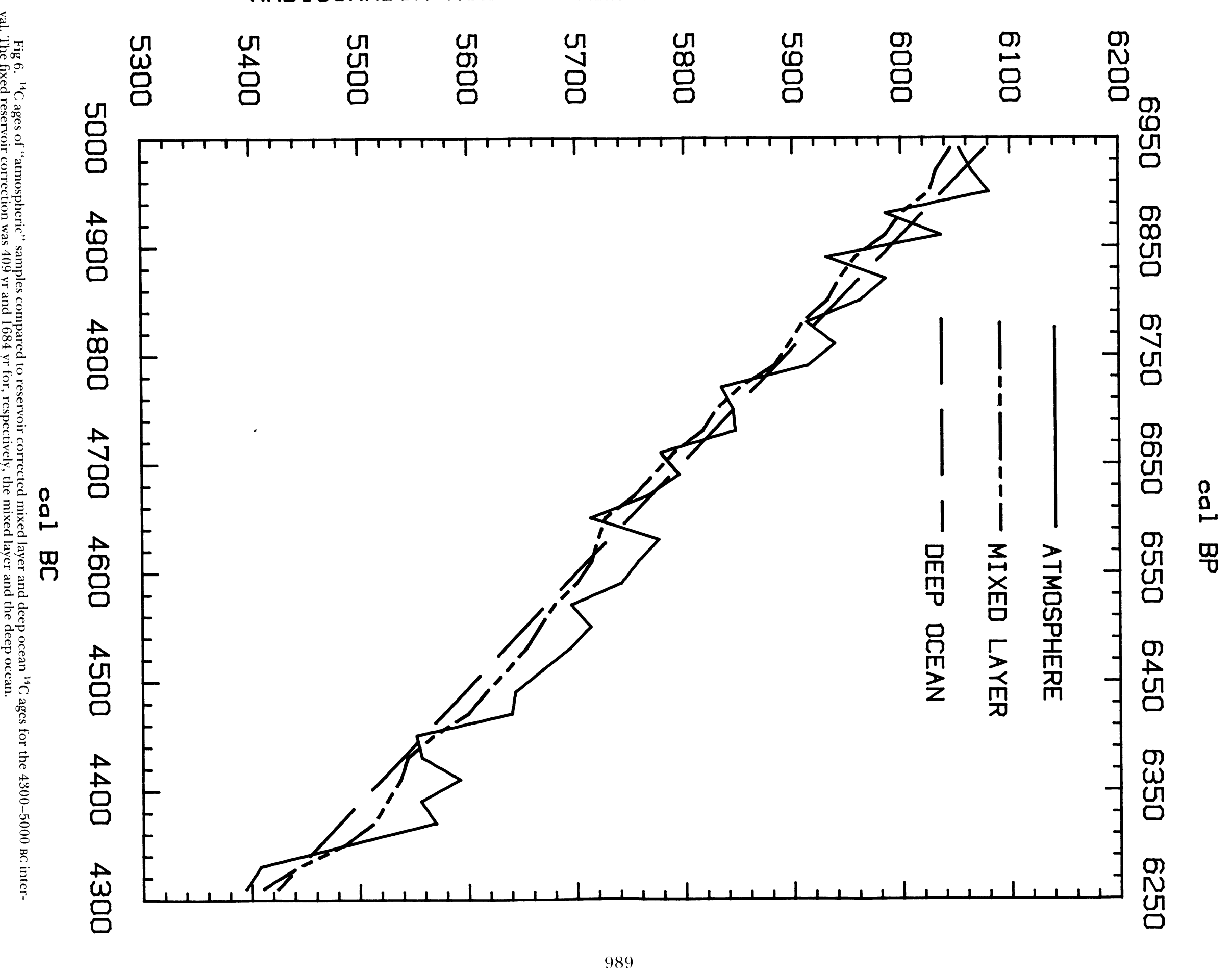


RADIOCARBON AGE - FIXED RESERVOIR AGE YRS BP

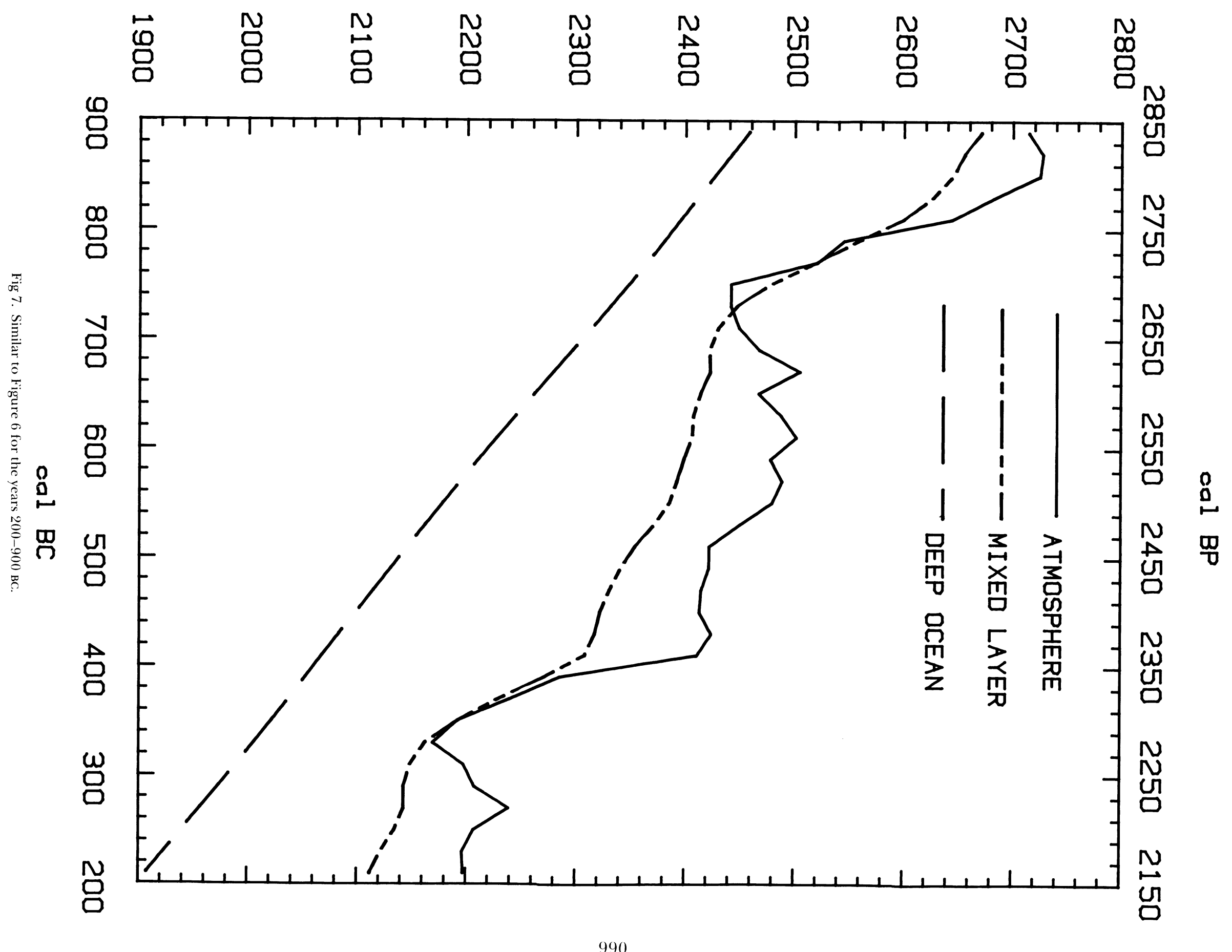




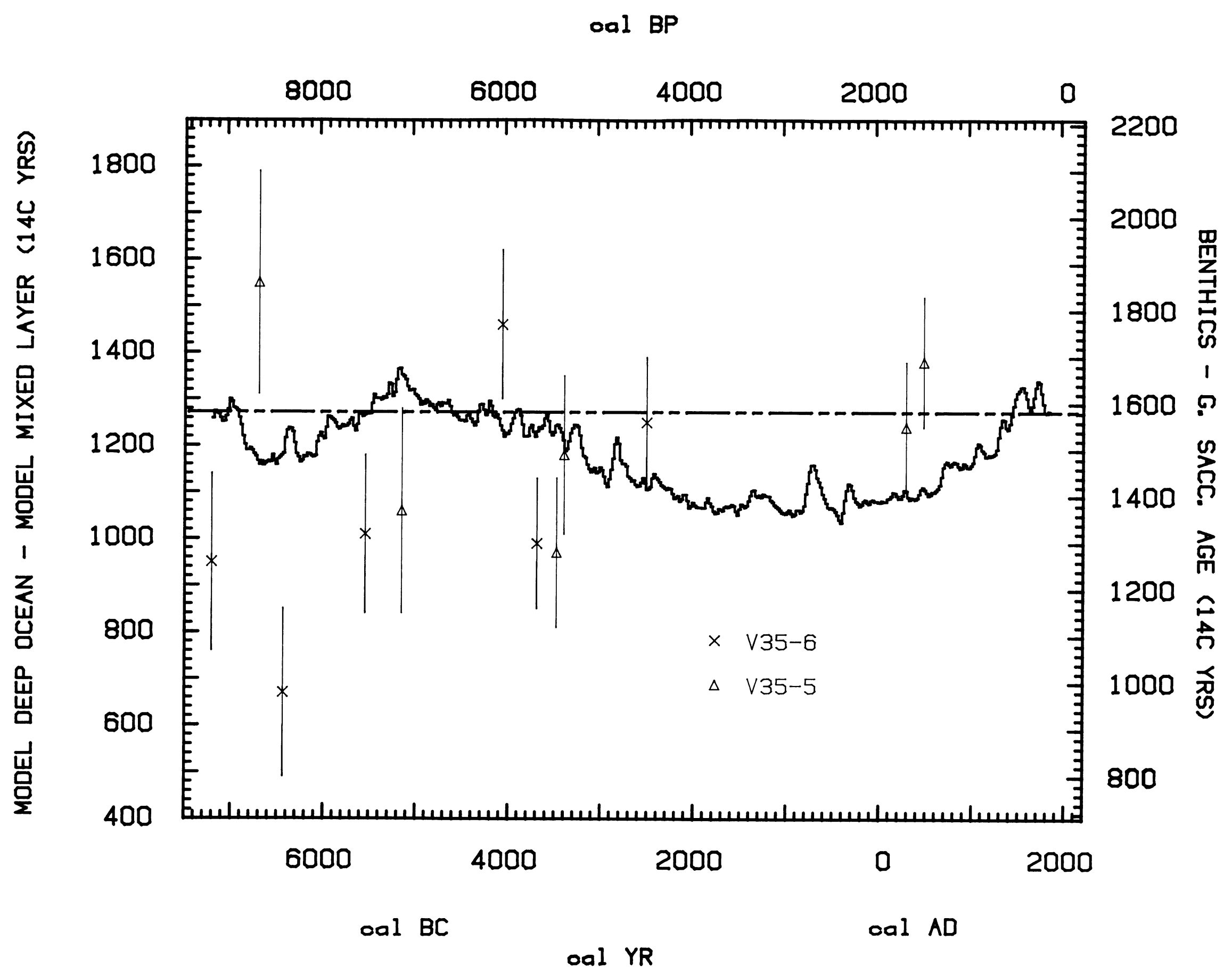

Fig 8. The calculated deep ocean-mixed layer ${ }^{14} \mathrm{C}$ age differences compared to benthic-planktonic differences measured by Andrée et al (1986a) for the South China Sea. The deep water in the China Sea is more ${ }^{14} \mathrm{C}$-deficient than our model ocean, causing a shift between the ${ }^{14} \mathrm{C}$ time scales of 1585 (latest pre-anthropogenic age difference in Andrée $e t$ al) minus $1275{ }^{14} \mathrm{C}$ years (model AD 1830 value), both indicated by the dotted line. 


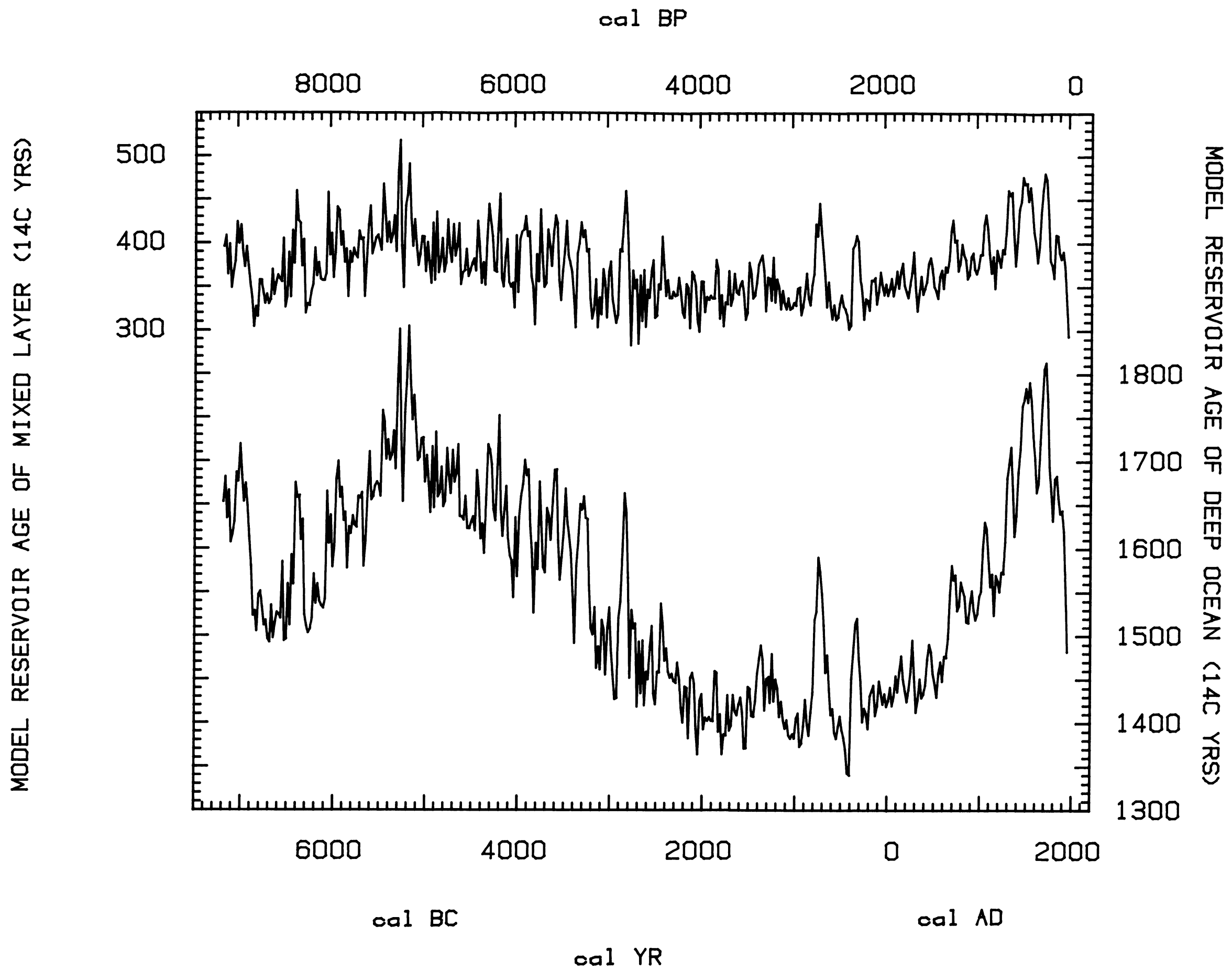

Fig 9. The changing pattern of model-calculated reservoir ages $\mathrm{R}(\mathrm{t})$ of the mixed layer (top curve) and the deep ocean (bottom curve). 
cal BP

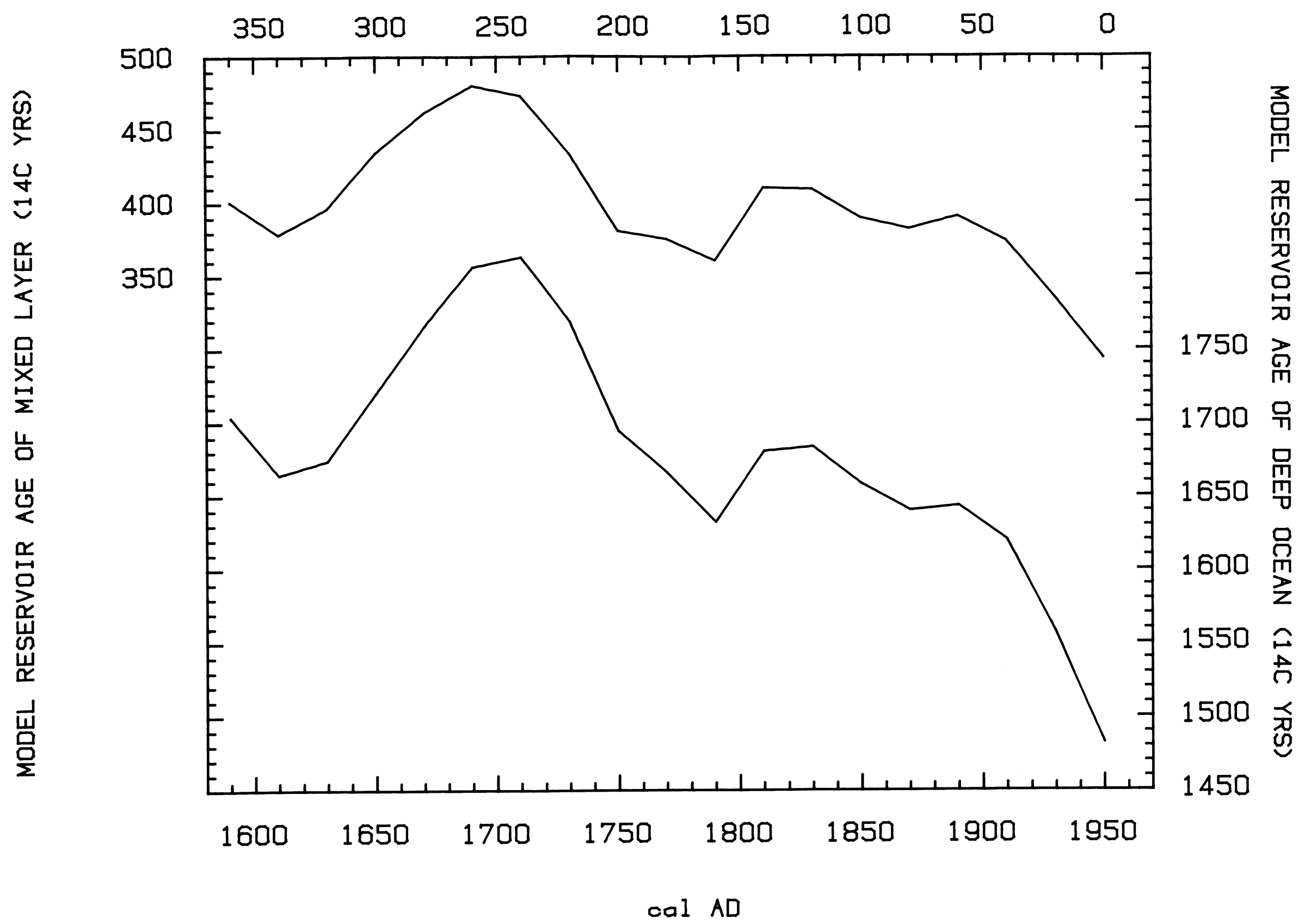


oal BP

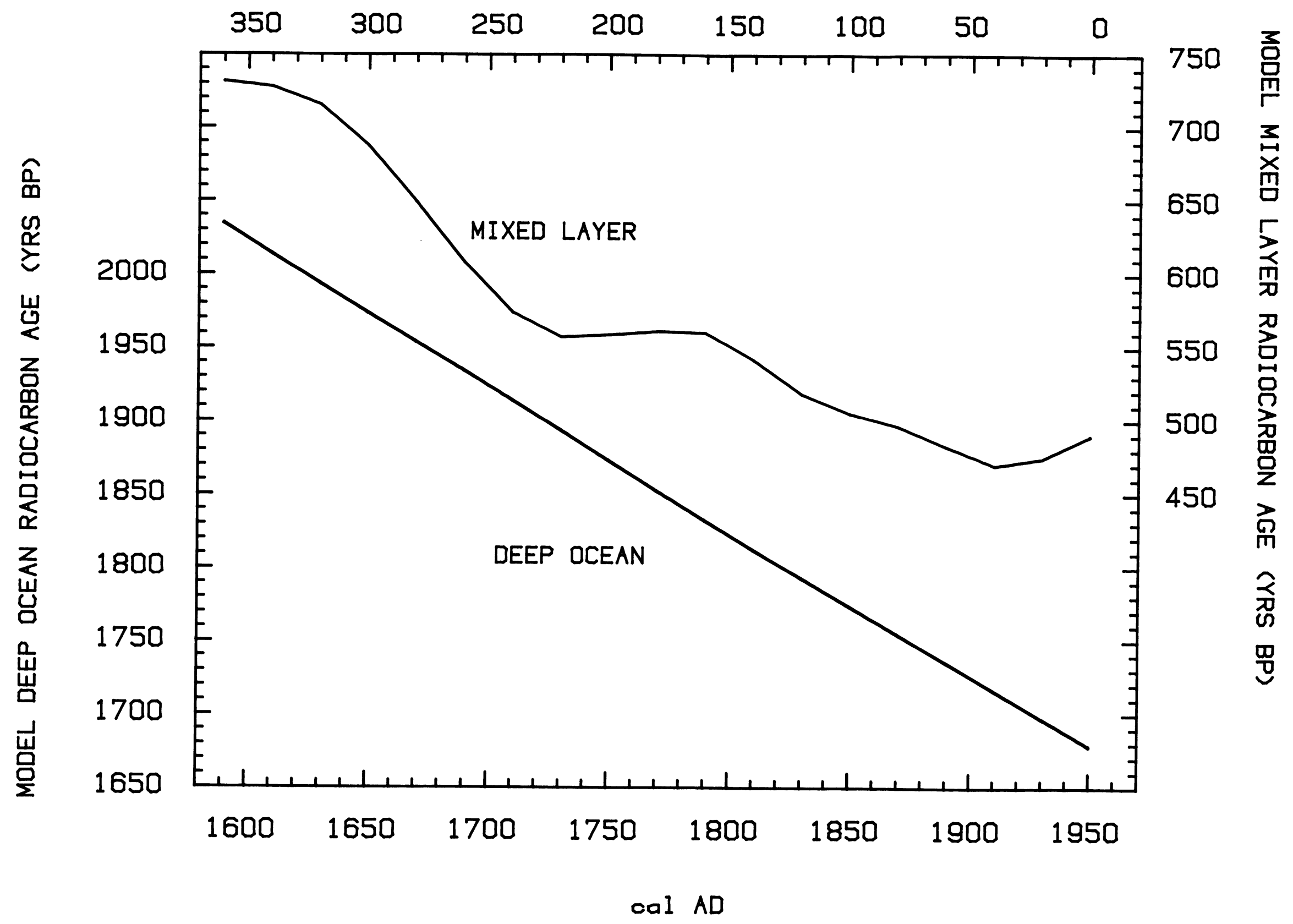

Fig 10A. Model-calculated conventional ${ }^{14} \mathrm{C}$ ages of the mixed layer and deep ocean for the $\mathrm{AD} 1600-1950$ interval. 


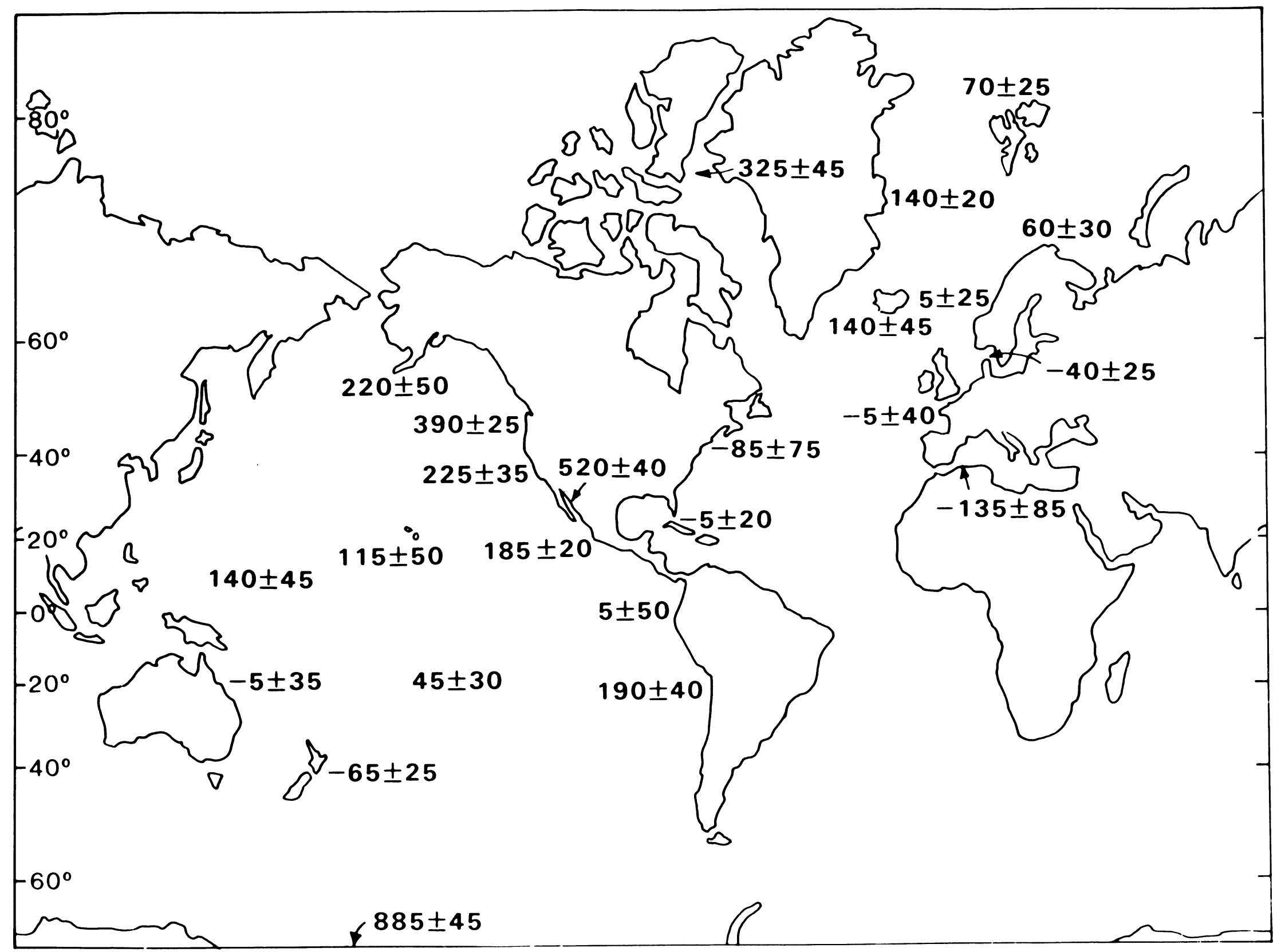

Fig $10 \mathrm{~B}$. Coastal region $\Delta \mathrm{R}$ values in ${ }^{14} \mathrm{C}$ yr as derived mostly from shell dates. The \pm values are minimum standard deviations based on the scatter of the data, or the measurement precision, whichever is larger (see Table 1 for details). 
CONVENTIONAL RADIOCARBON AGE $-\triangle R$ (YRS BP)

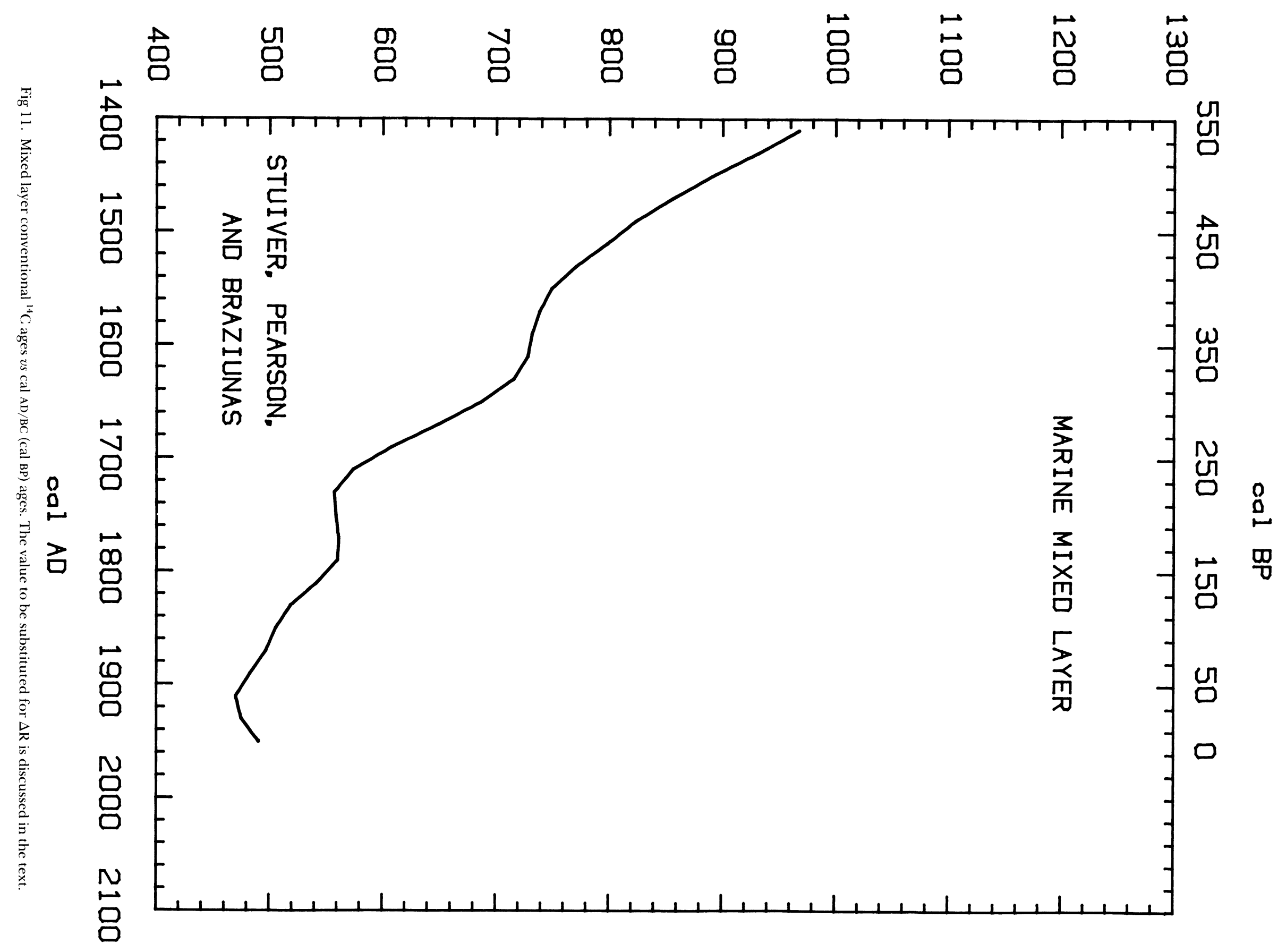


cal BP

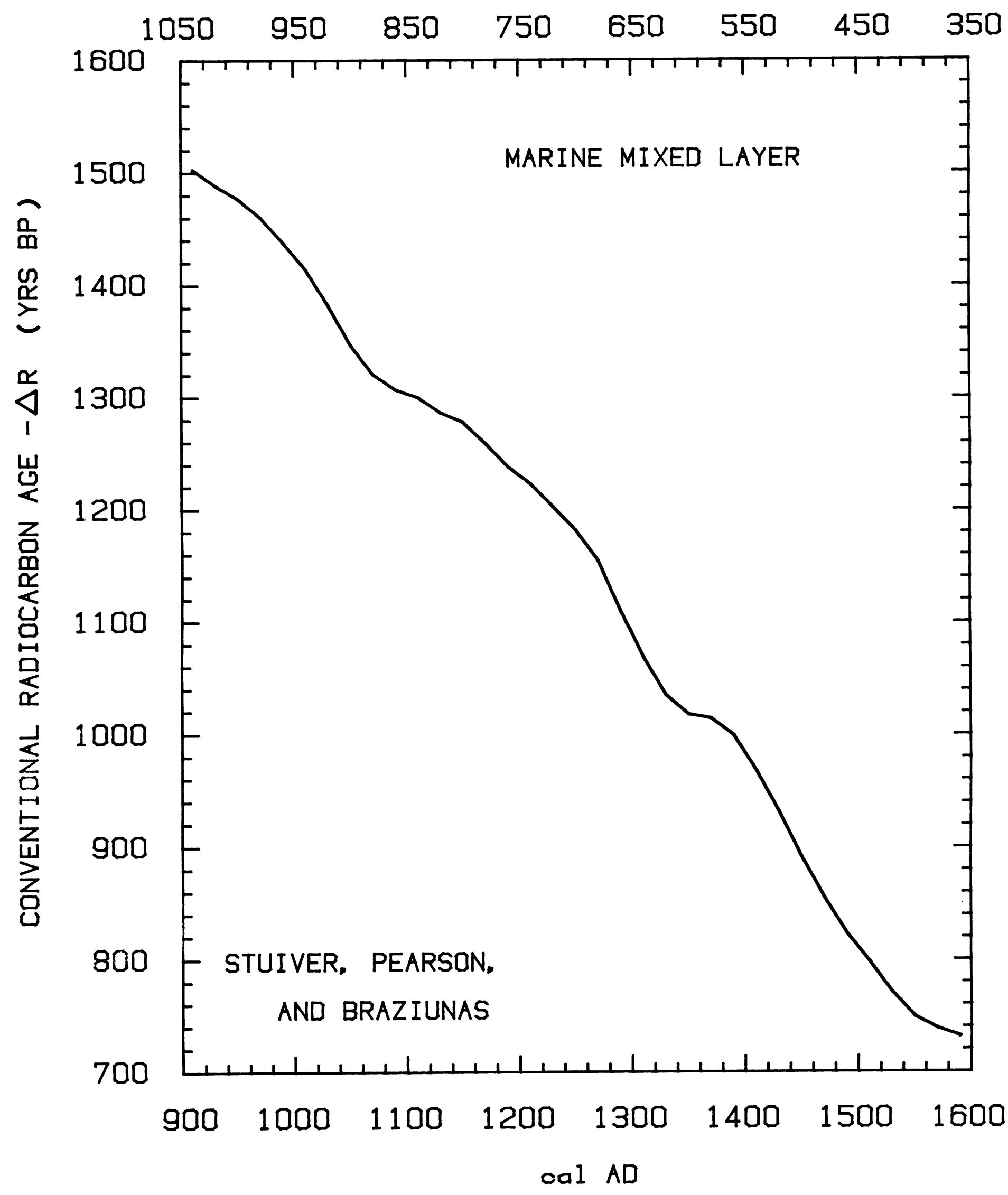

Fig $11 \mathrm{~B}$ 


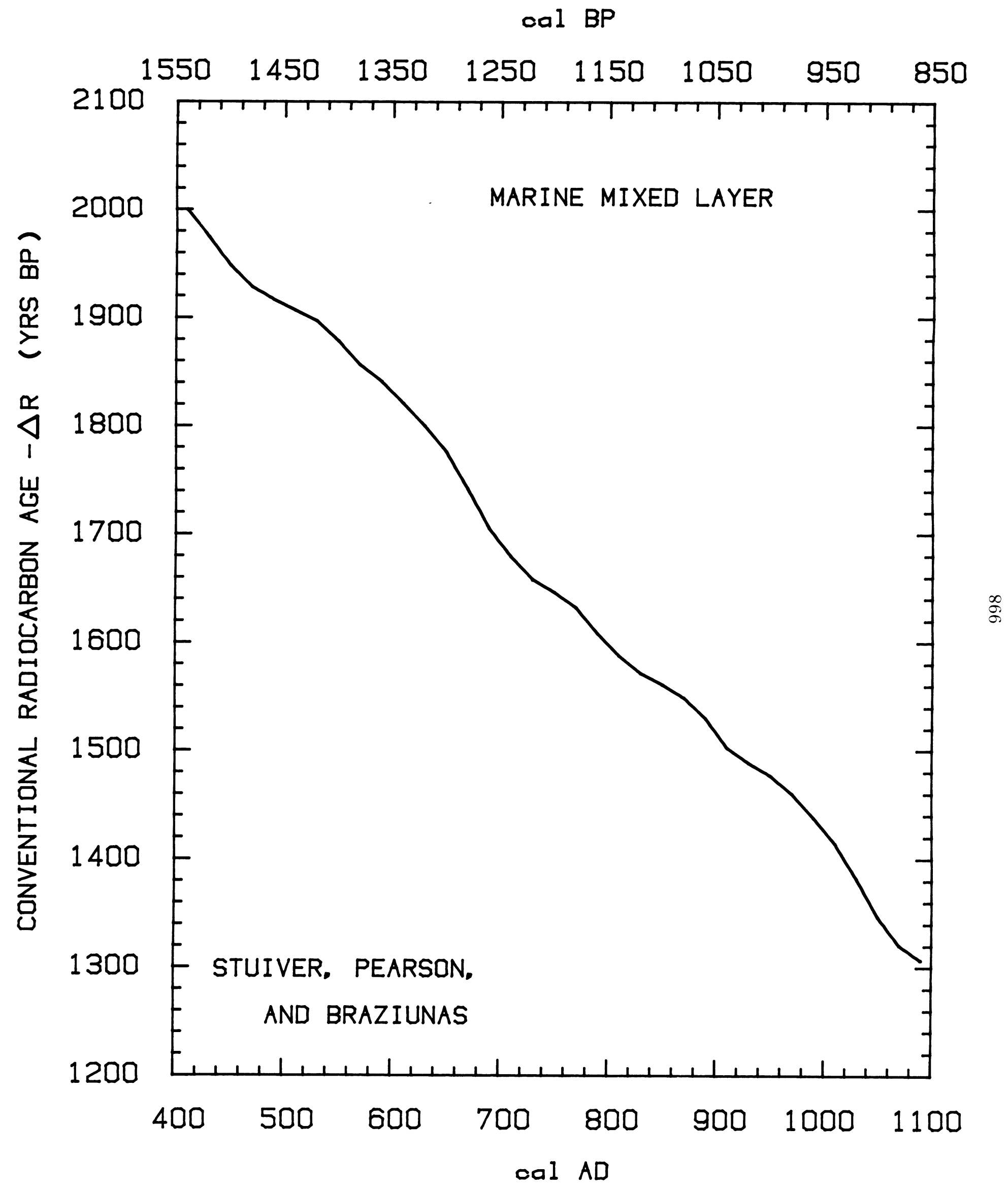

Fig $11 \mathrm{C}$ 


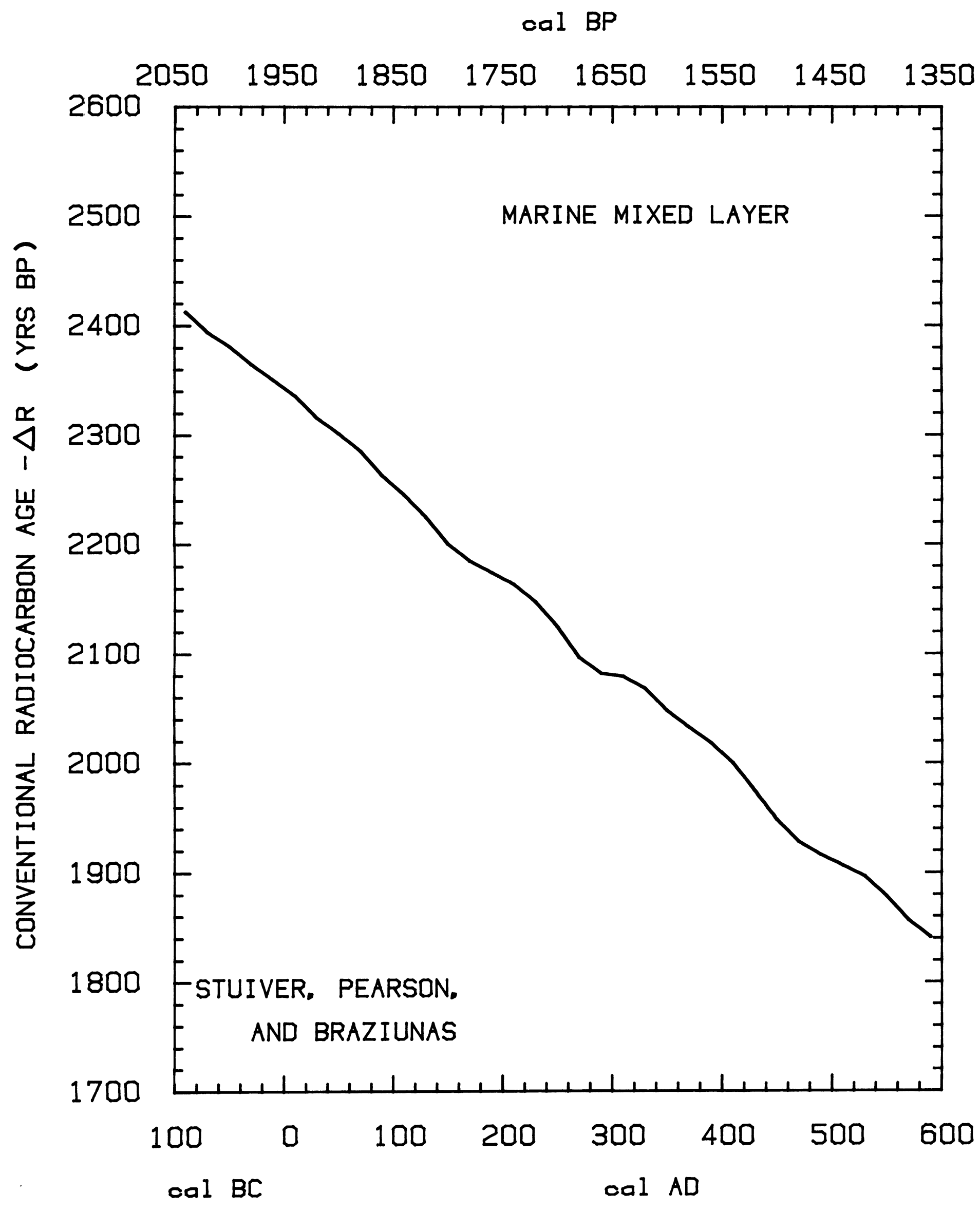

Fig 11D 


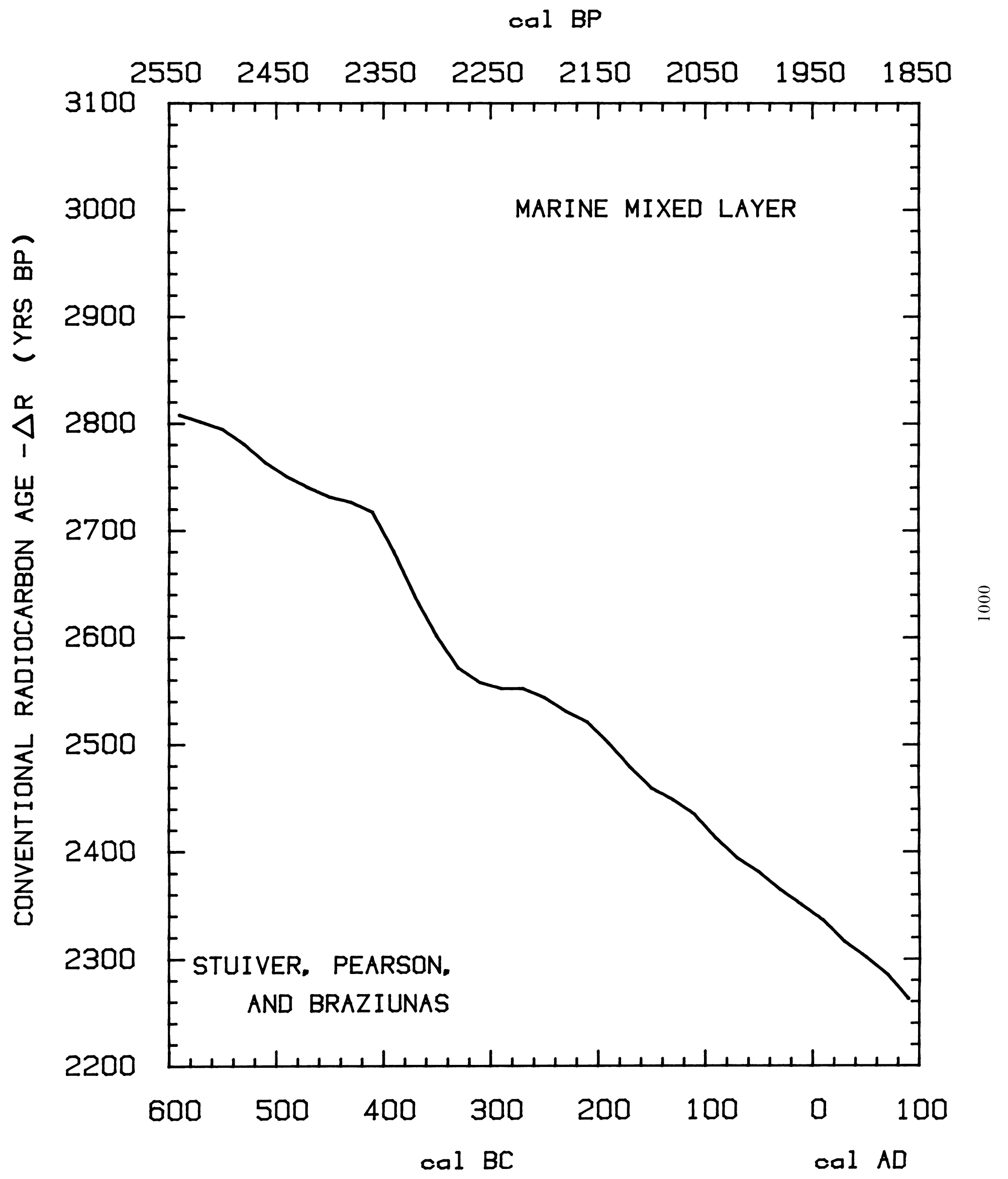

Fig $11 \mathrm{E}$ 


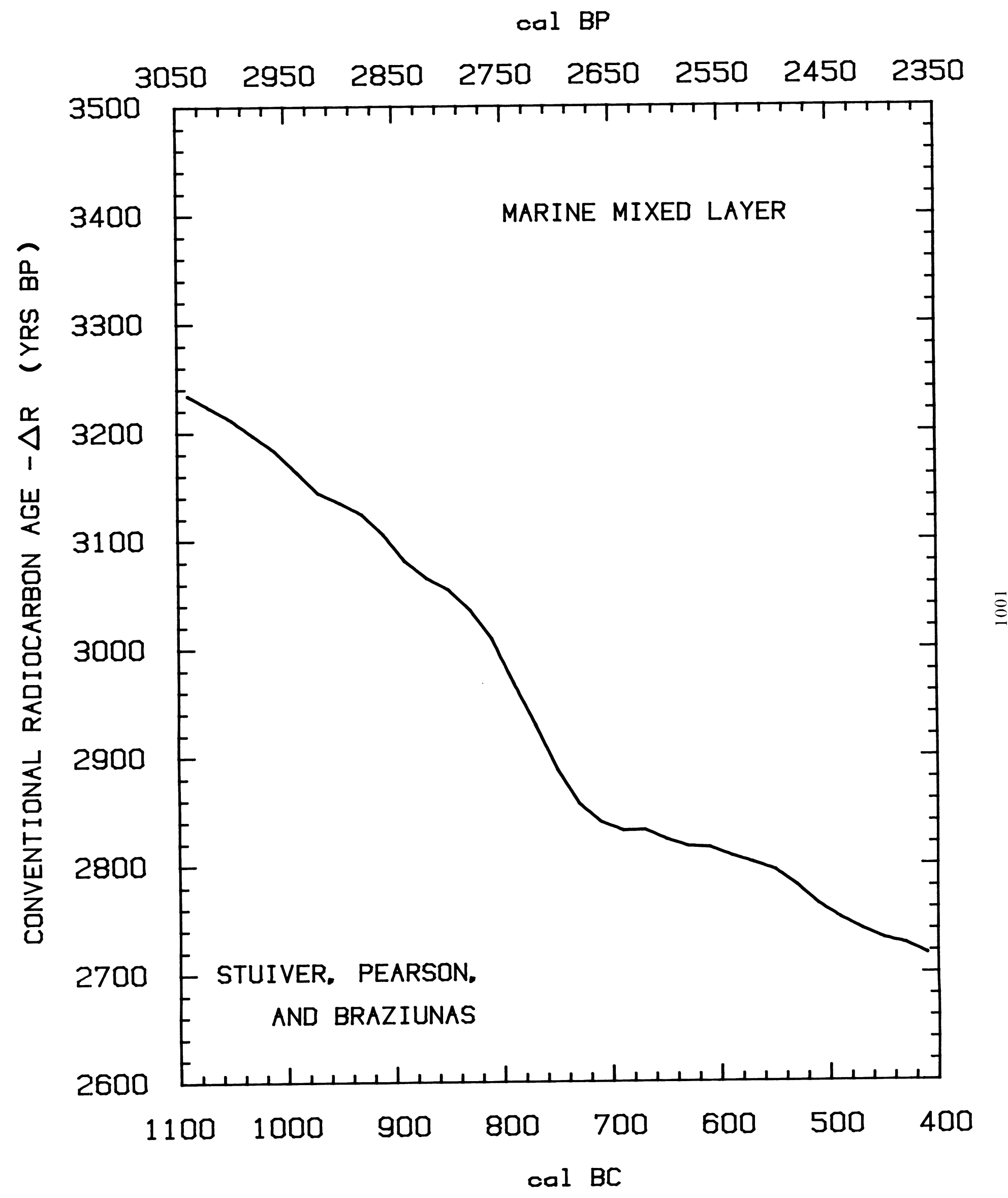

Fig $11 \mathrm{~F}$ 
cal BP

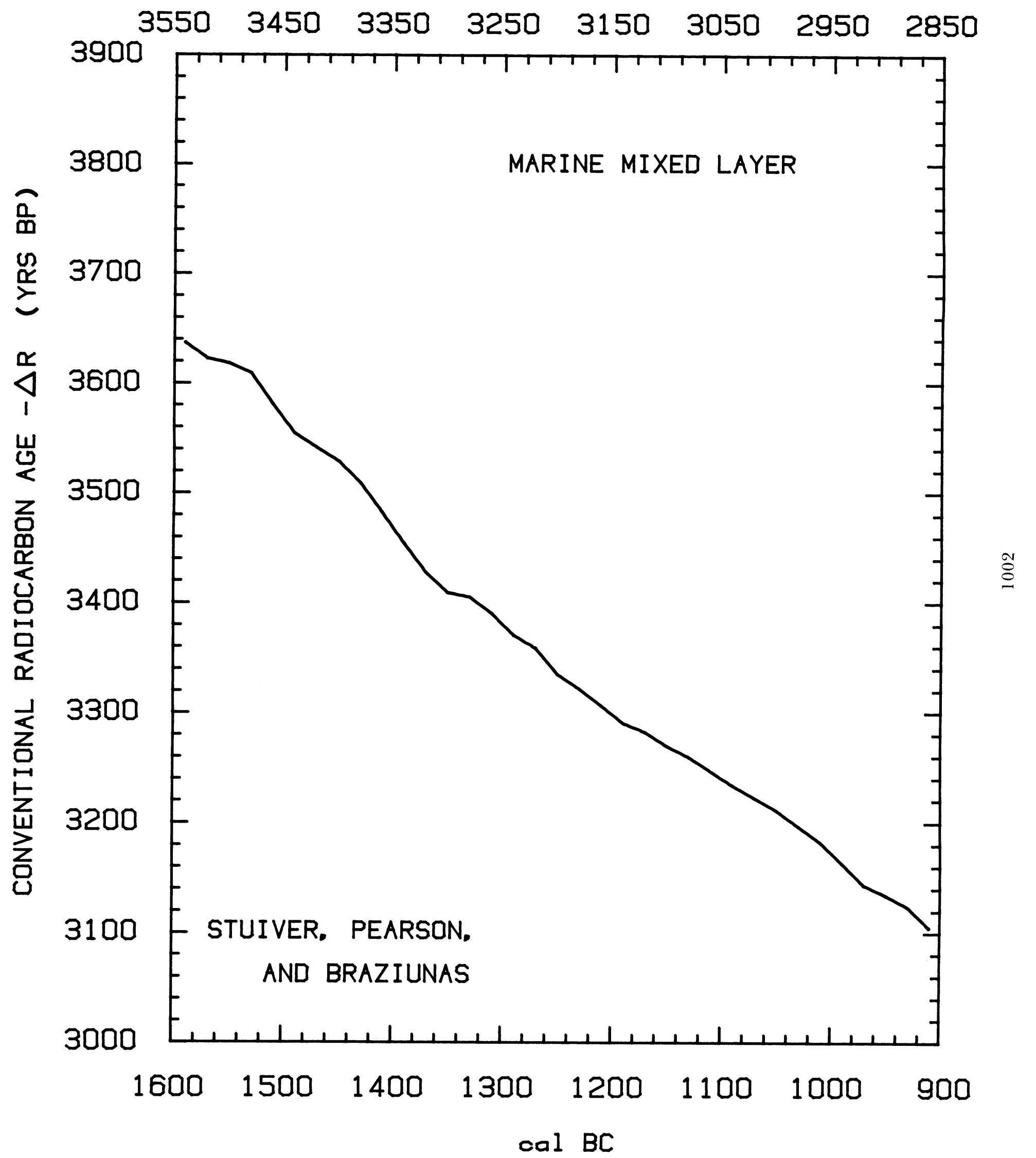

Fig $11 \mathrm{G}$ 
cal BP

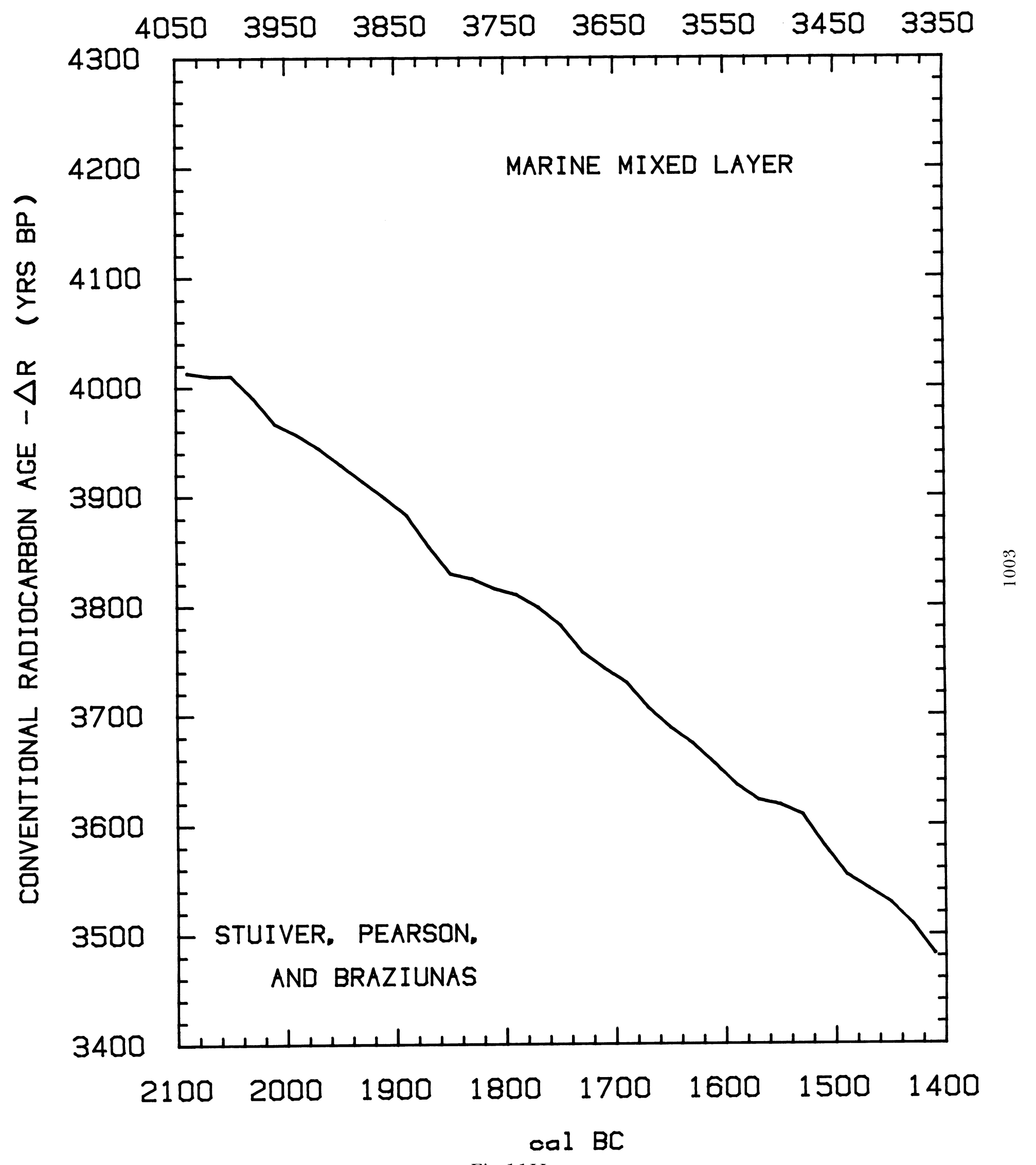

Fig $11 \mathrm{H}$ 


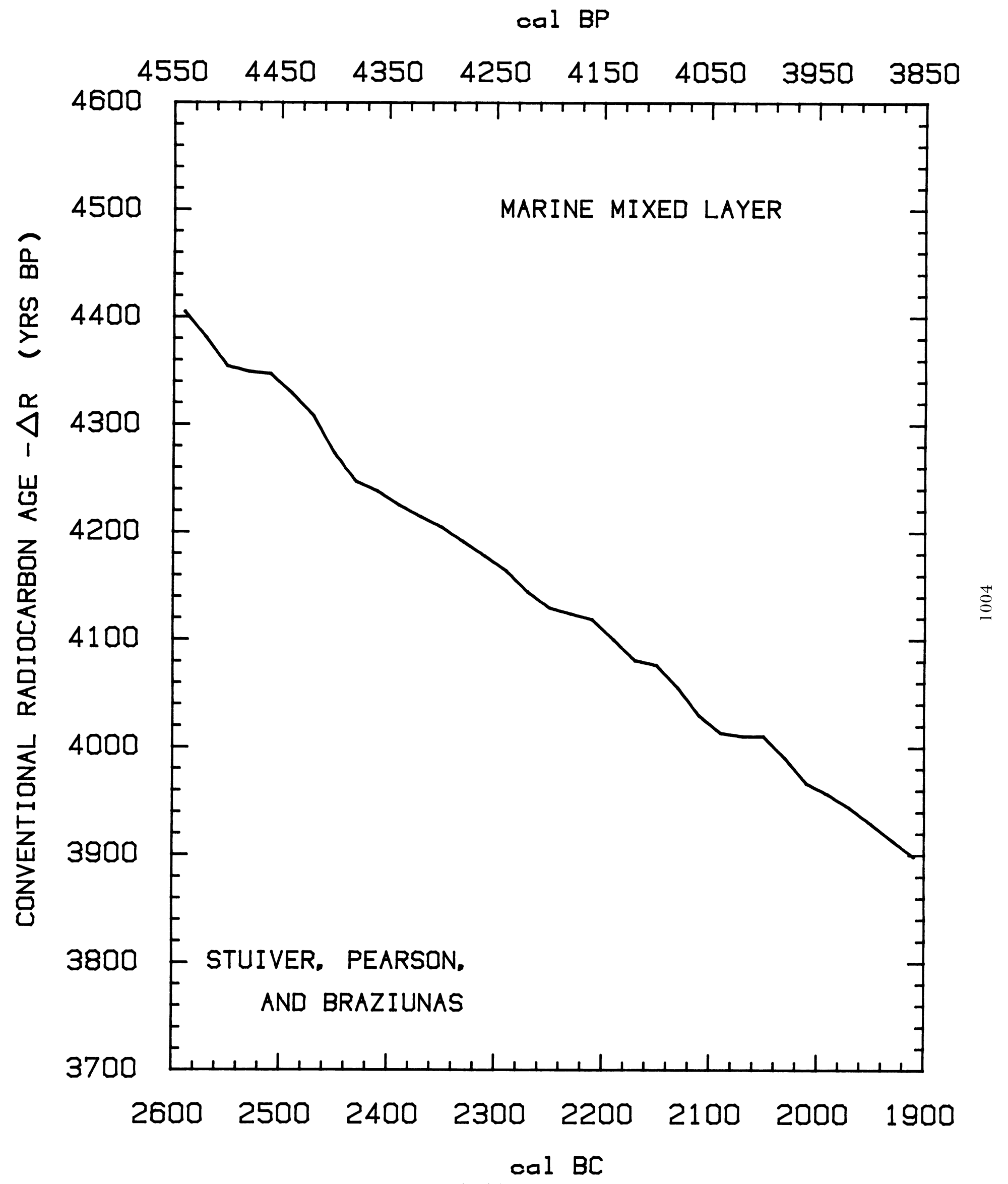

Fig $11 \mathrm{I}$ 


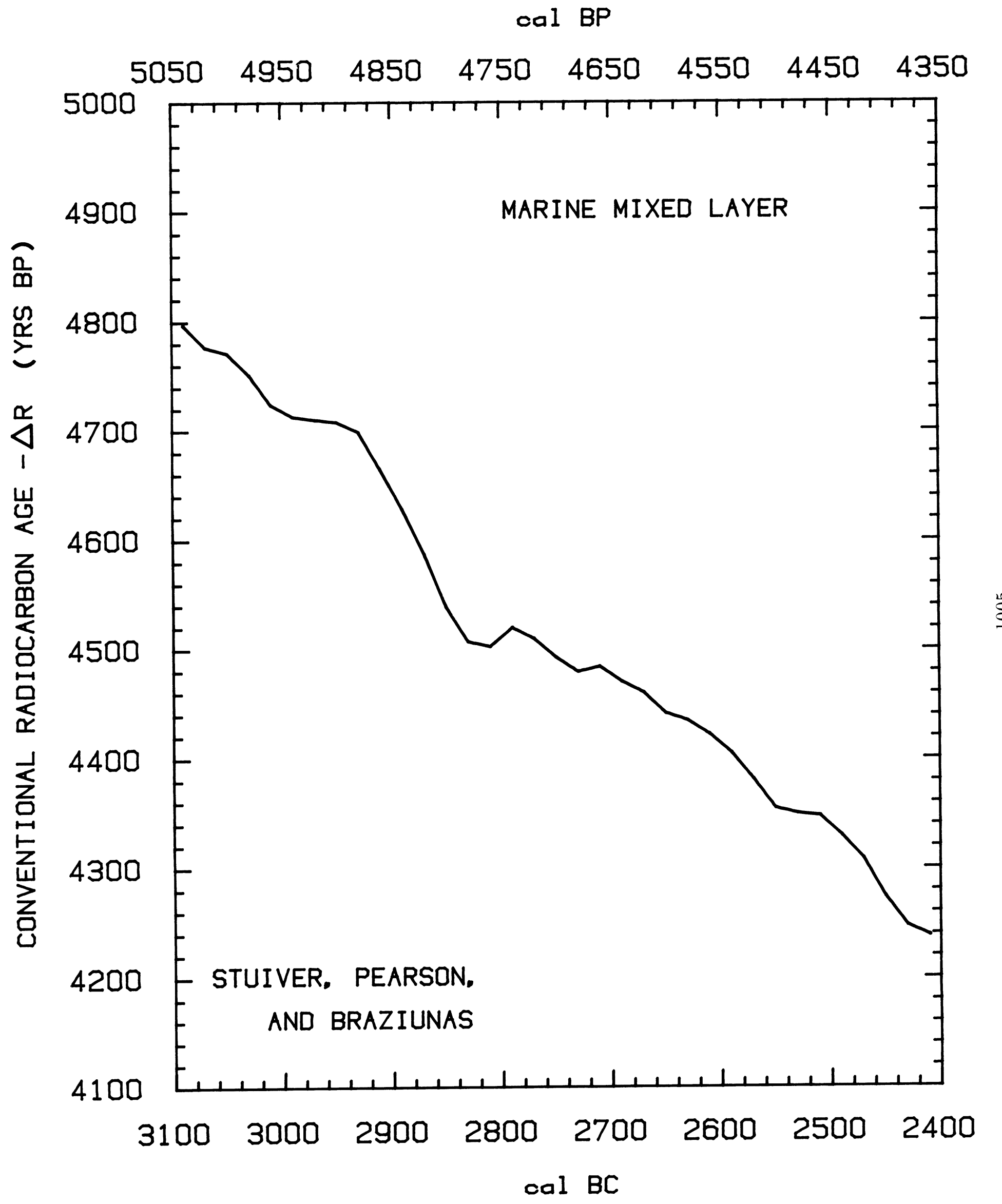

Fig 11J 


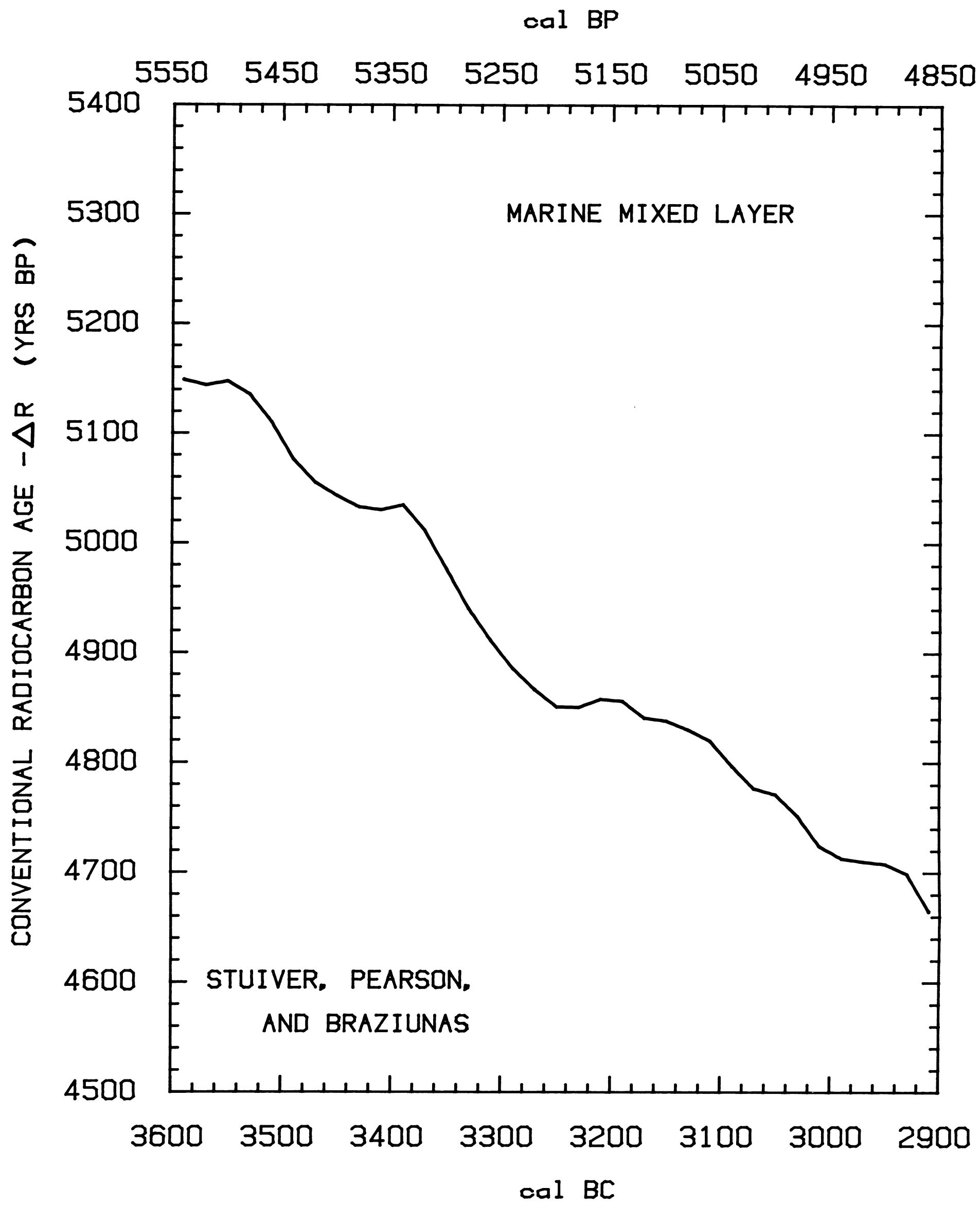

Fig $11 \mathrm{~K}$ 


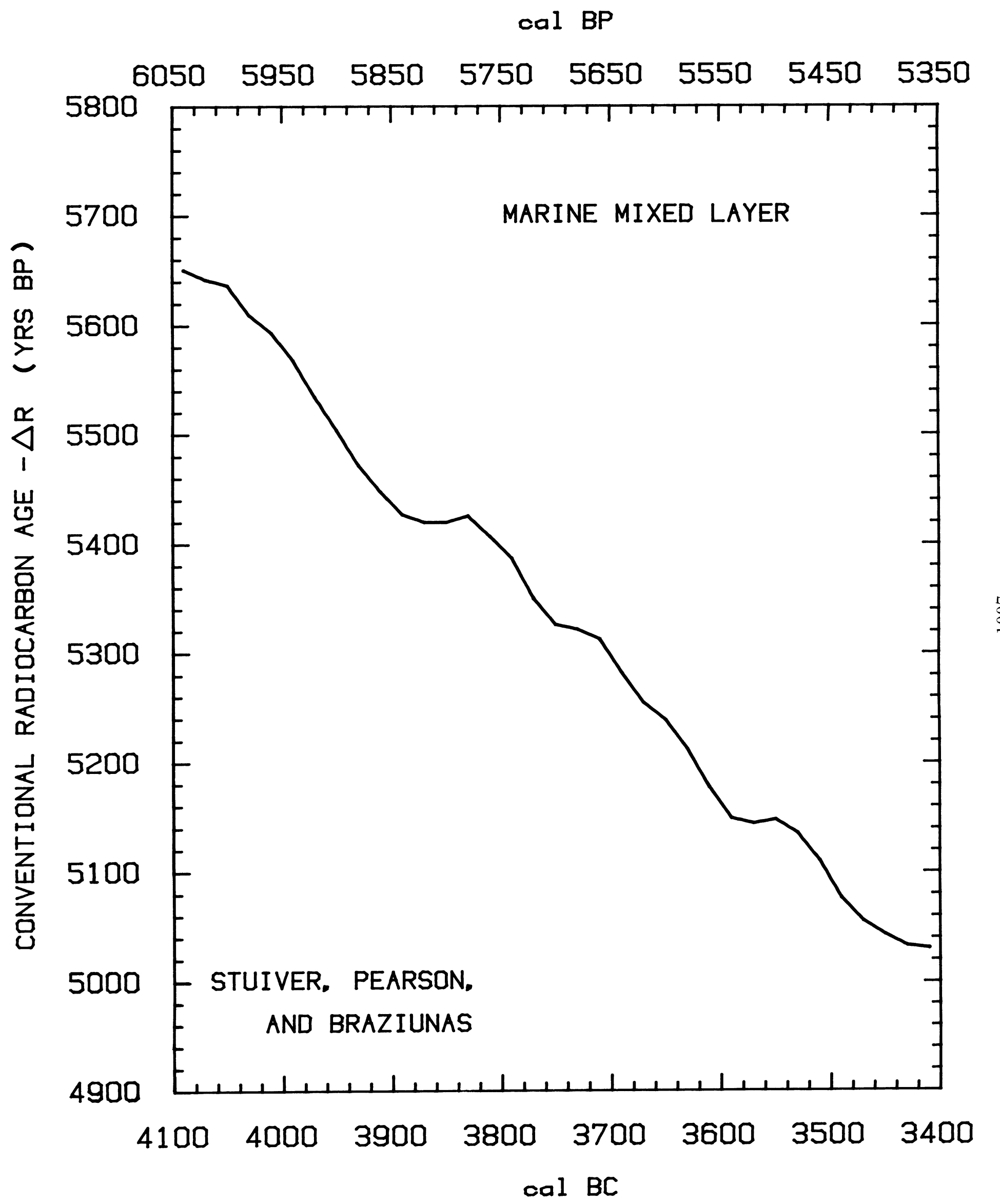

Fig $11 \mathrm{~L}$ 


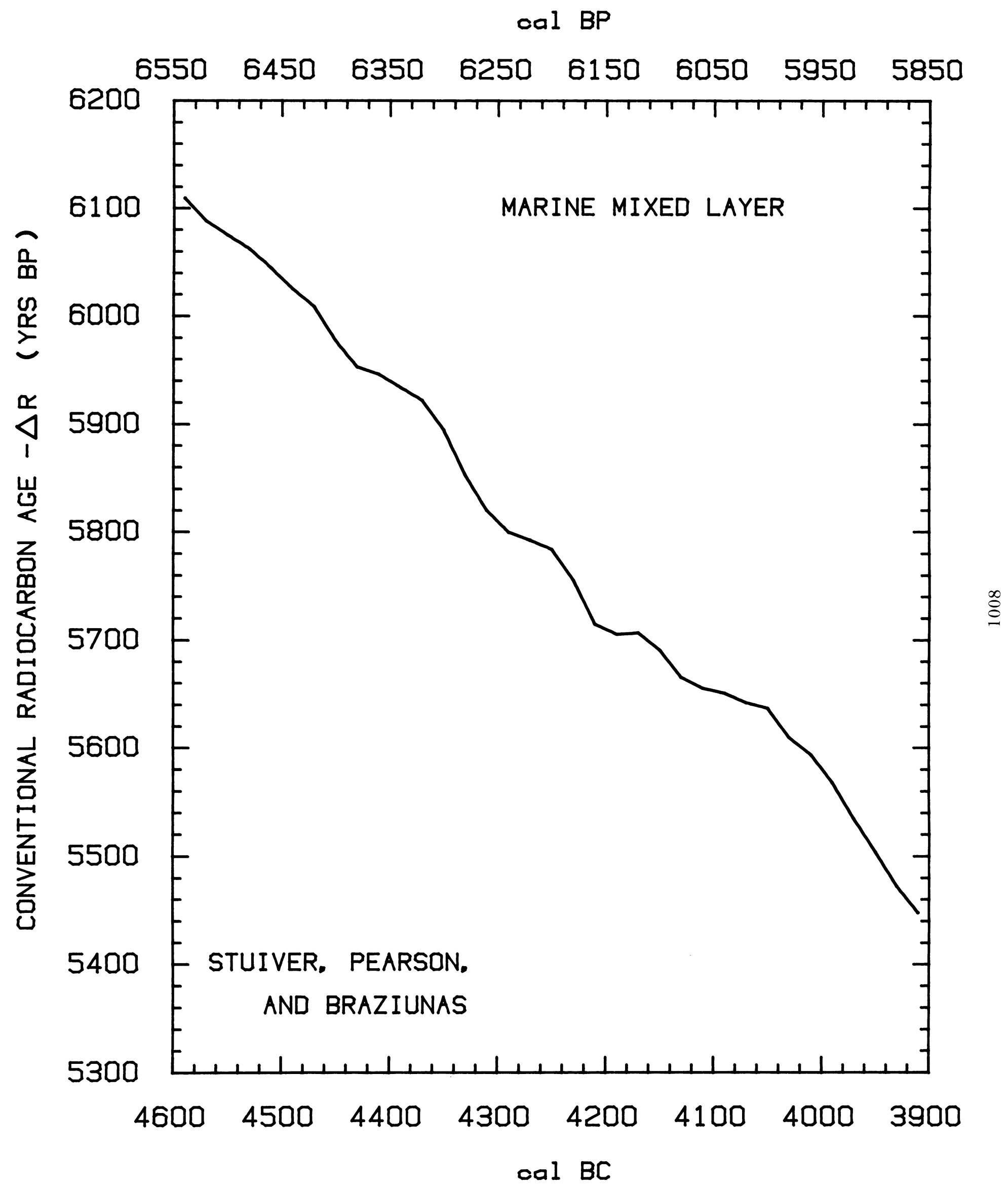

Fig $11 \mathrm{M}$ 
cal BP

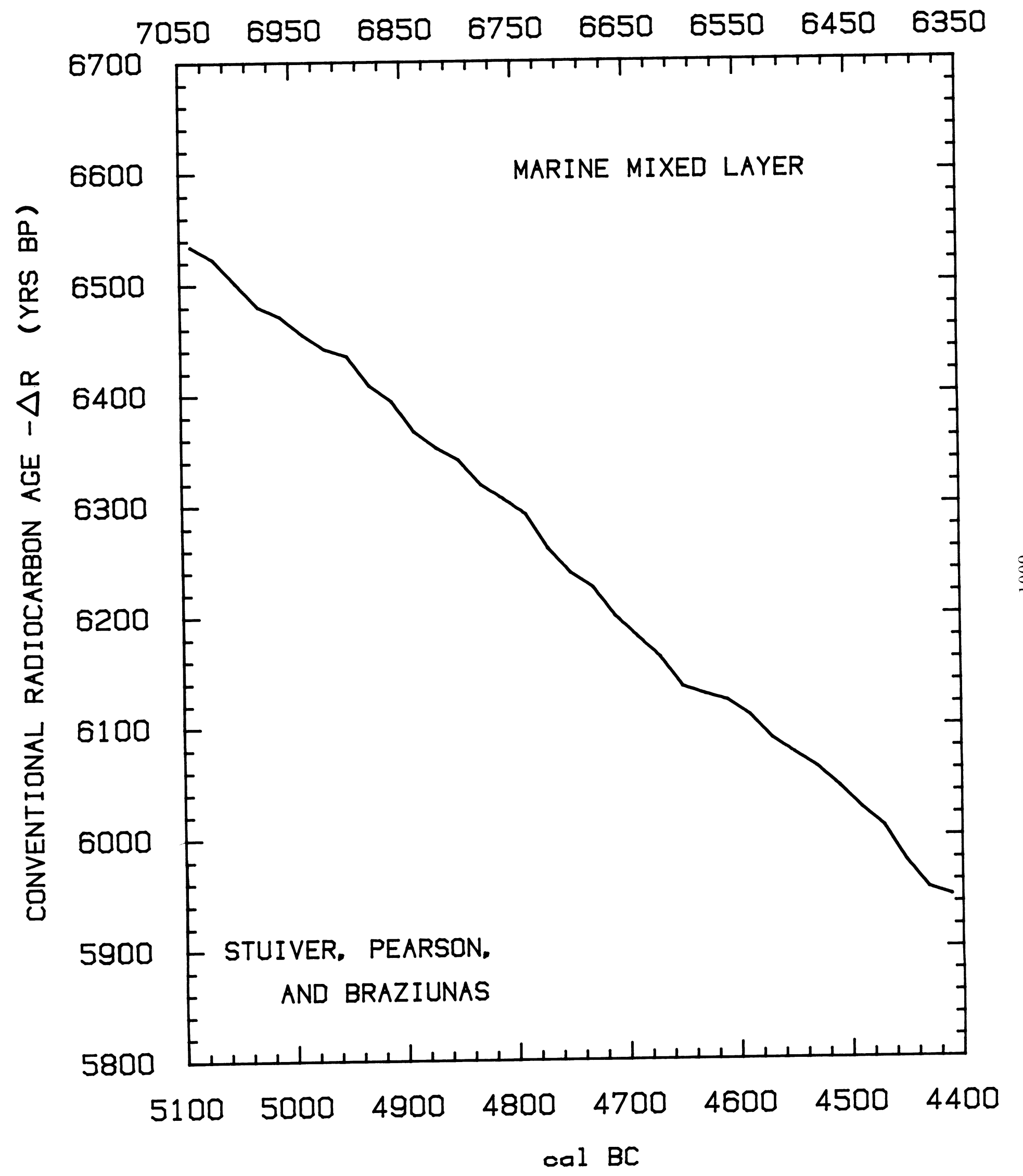

Fig $11 \mathrm{~N}$ 


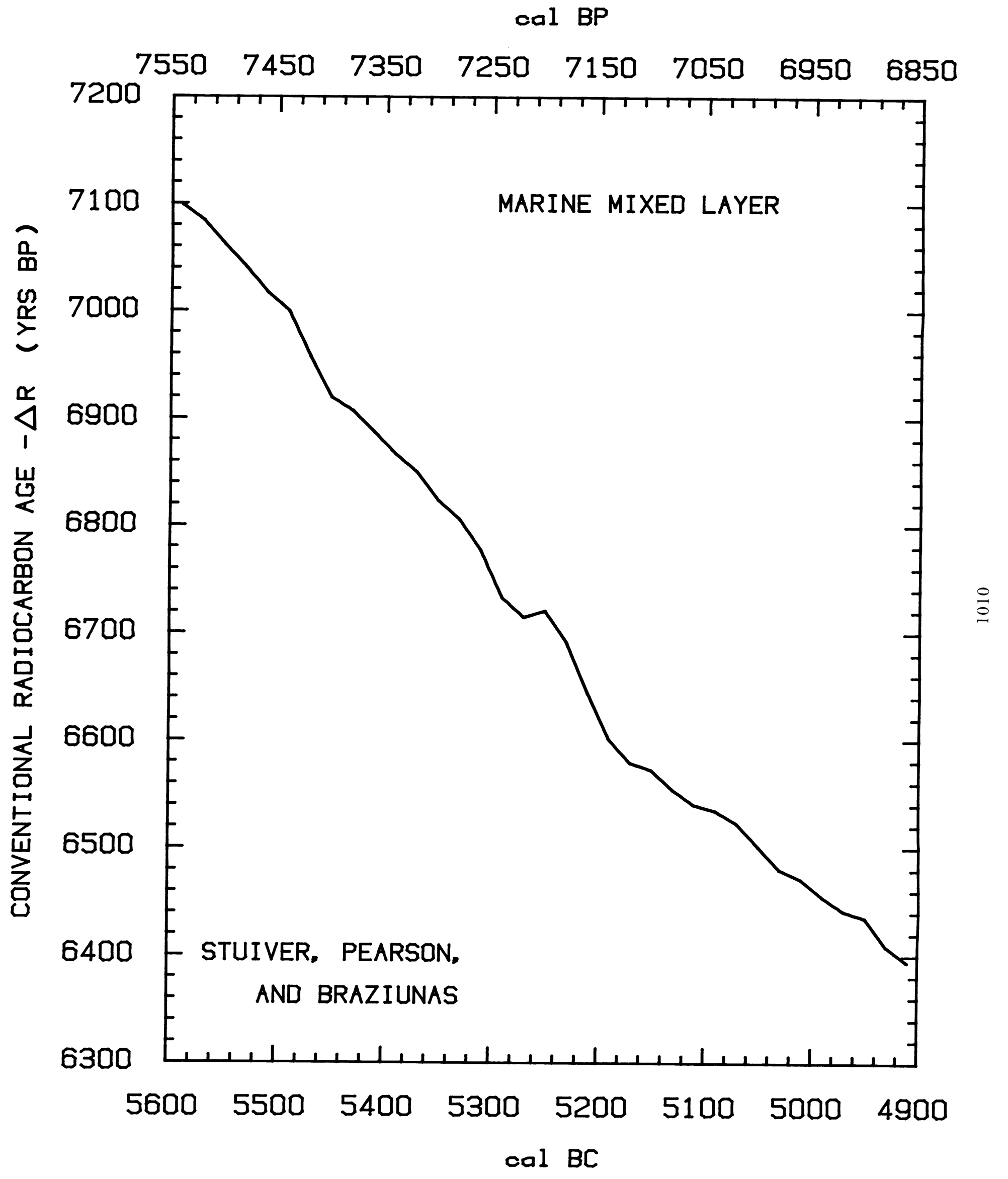

Fig 110 


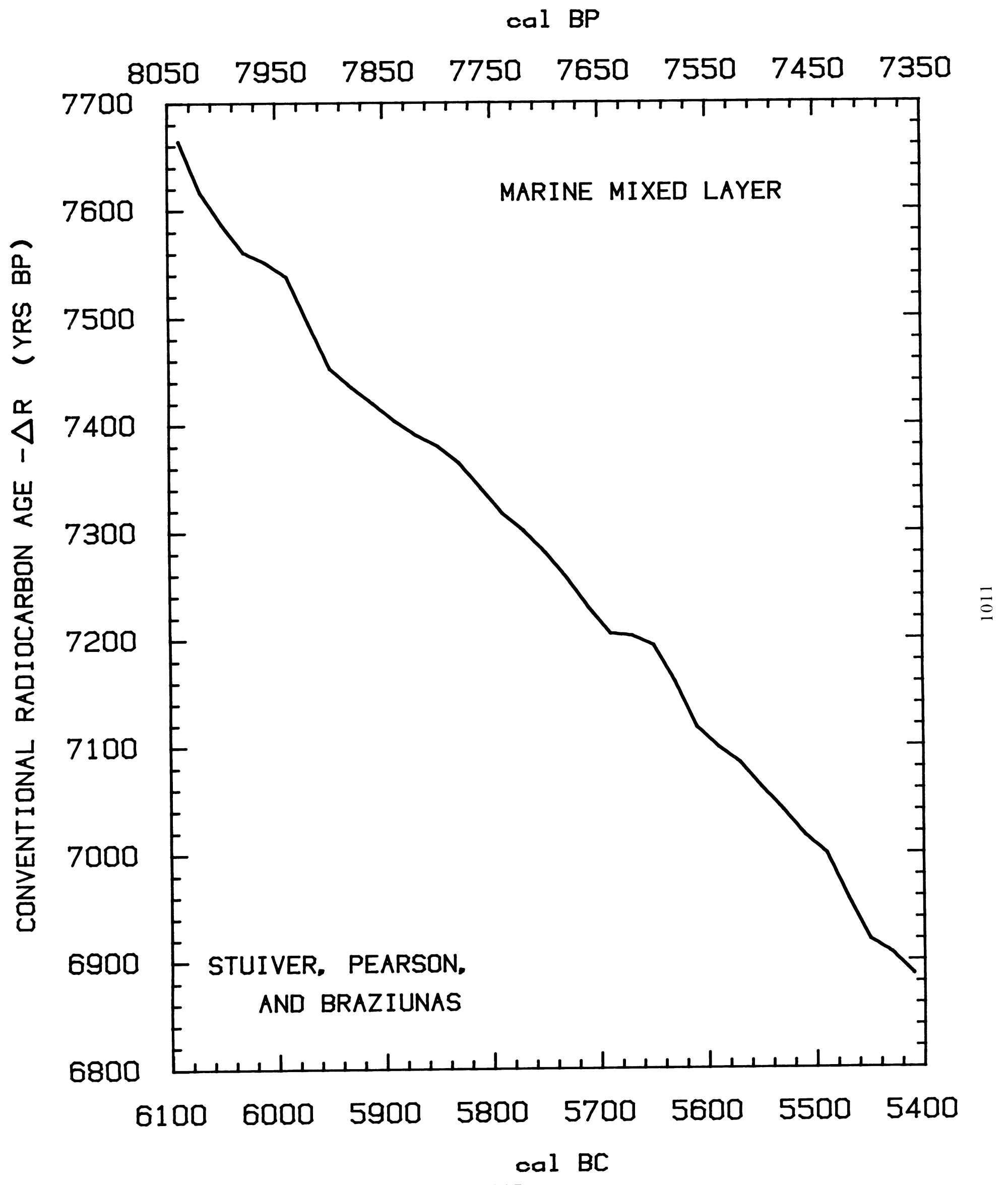

Fig $11 \mathrm{P}$ 


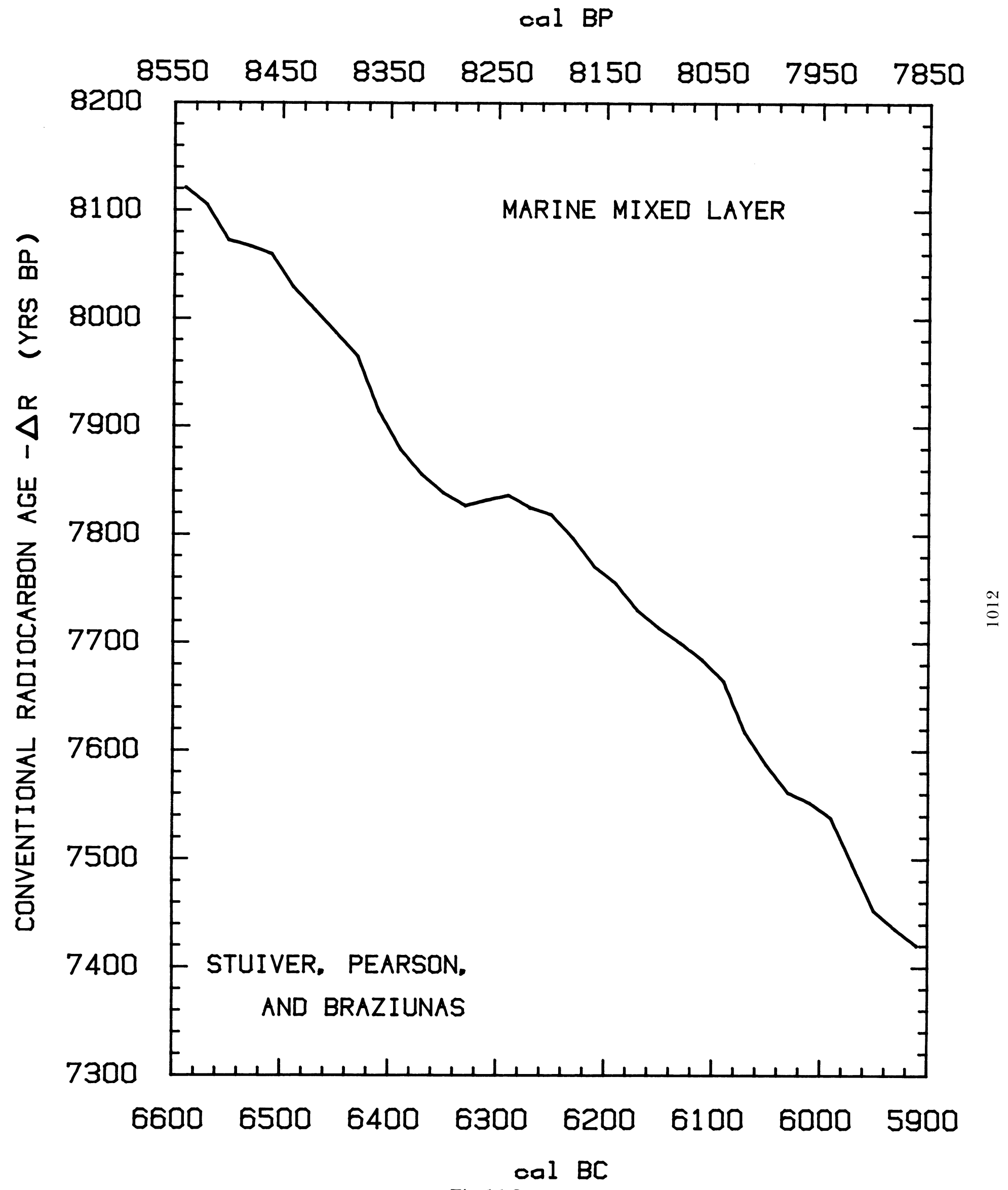

Fig $11 Q$ 
cal BP

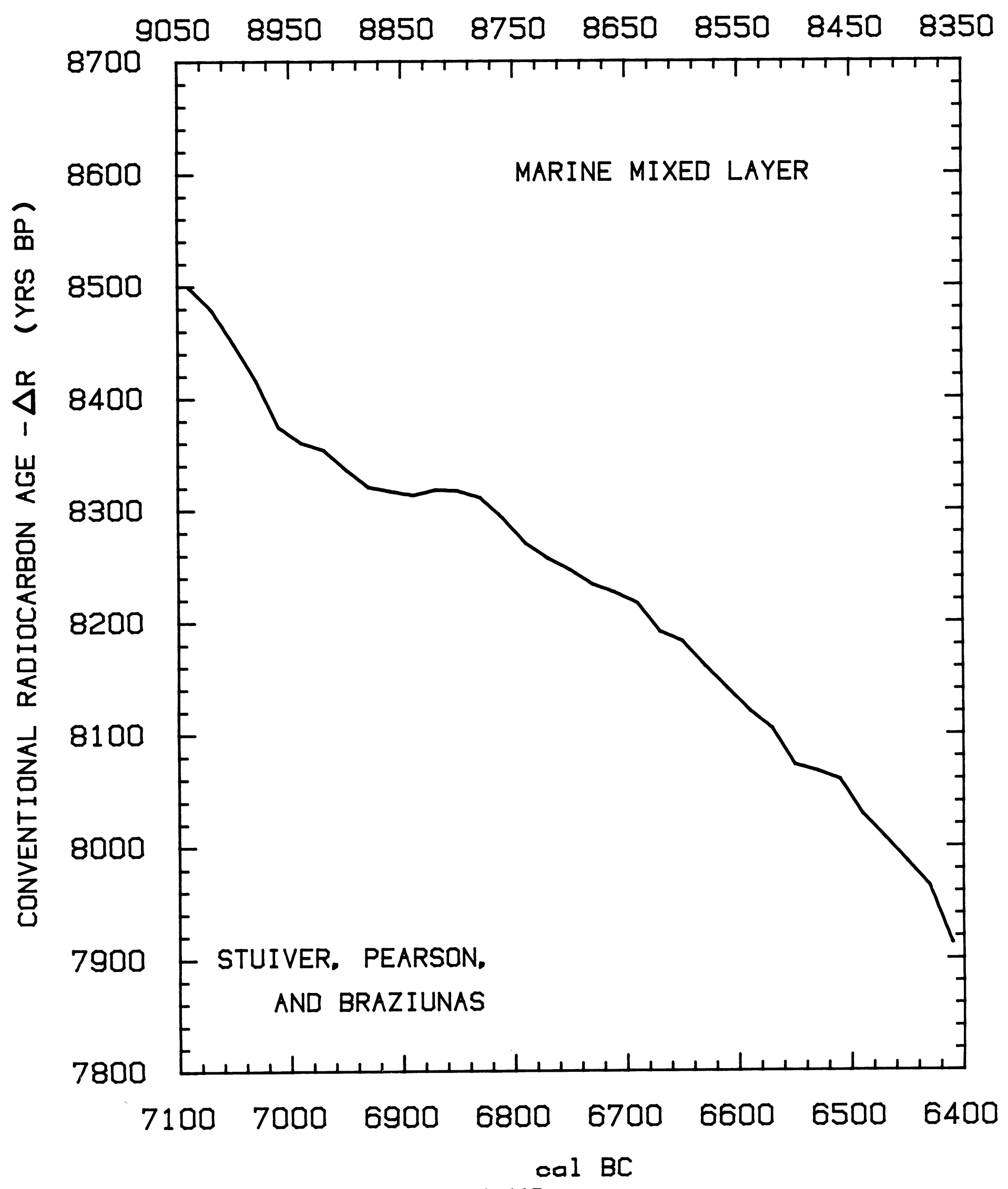

Fig $11 \mathrm{R}$ 
cal BP

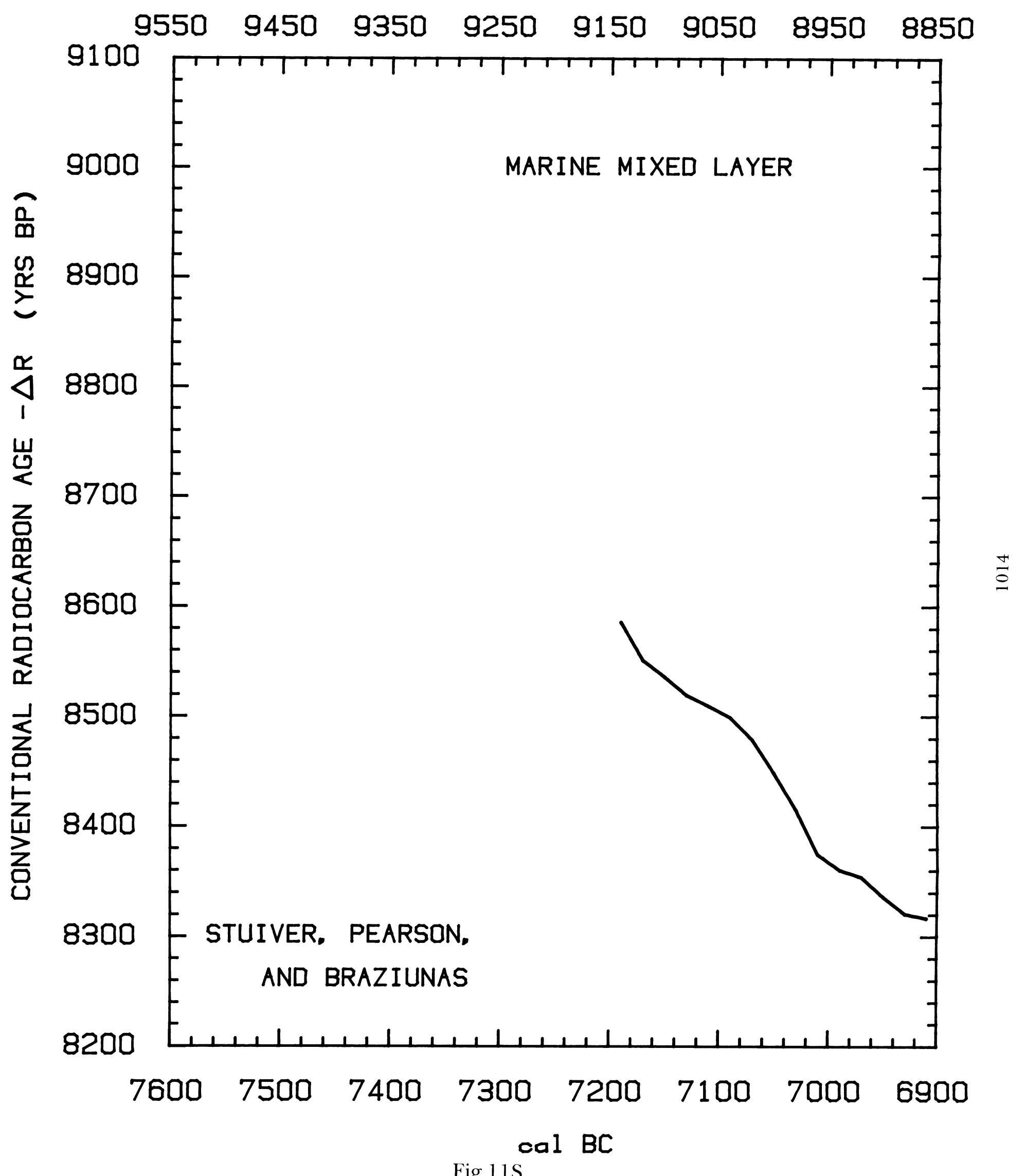




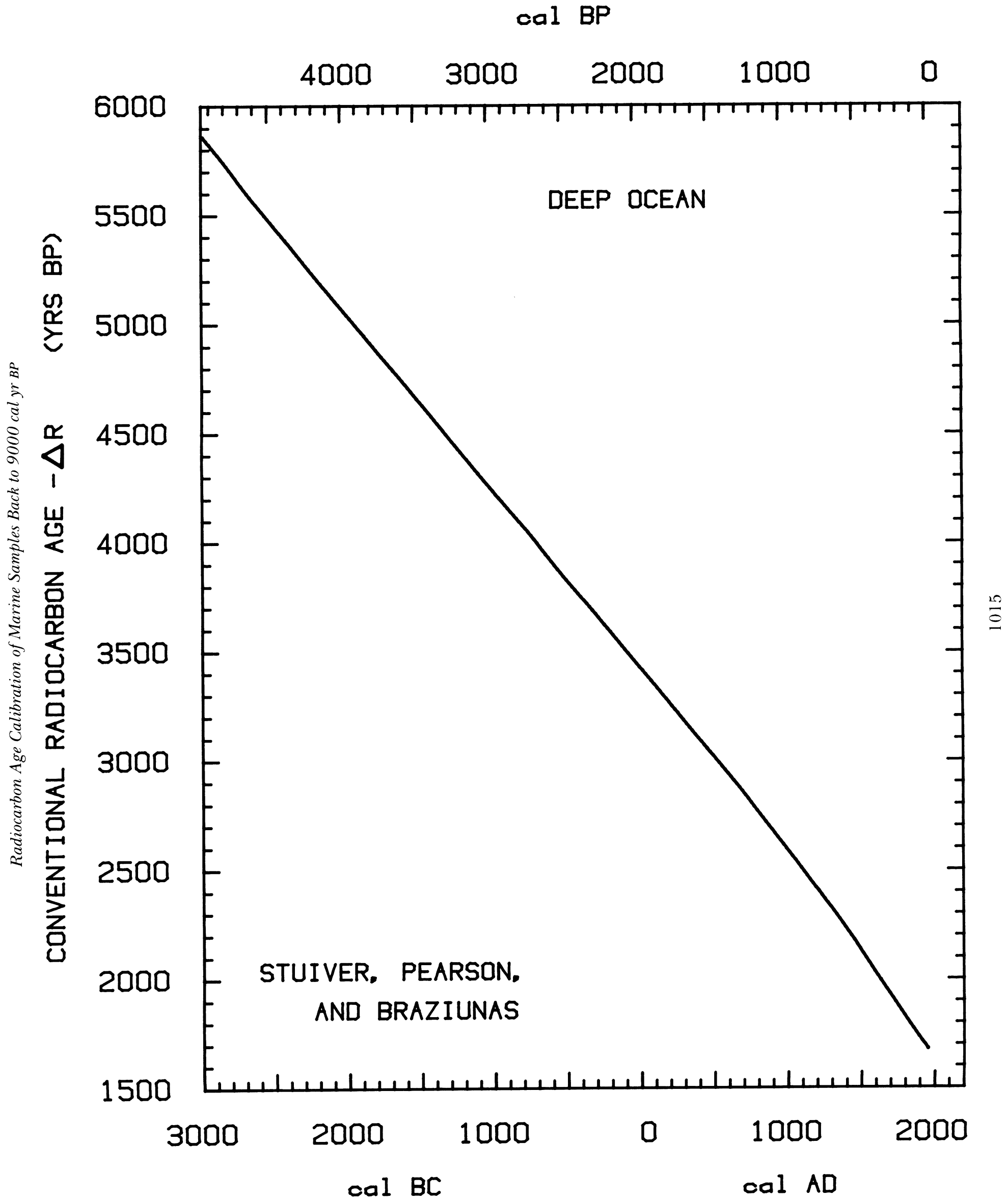

Fig 12. Deep ocean conventional ${ }^{14} \mathrm{C}$ ages $v s$ cal $\mathrm{AD} / \mathrm{BC}$ (cal BP) ages. $\Delta \mathrm{R}$ is discussed in the text. 


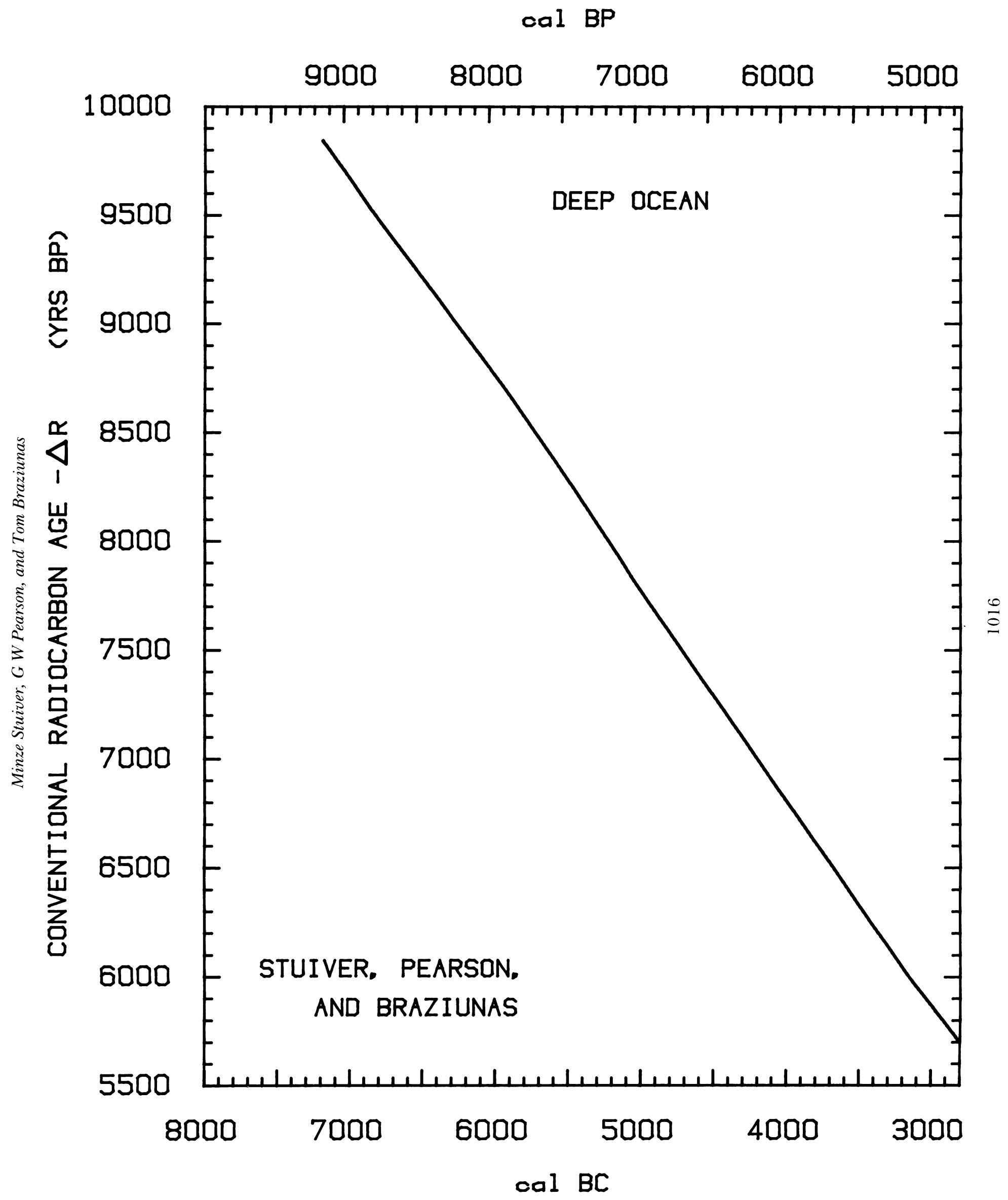

Fig 12B 
TABLE 1

Marine radiocarbon ages and $\Delta \mathrm{R}$ values of mostly shell samples of known historic age

\begin{tabular}{|c|c|c|c|c|c|}
\hline $\begin{array}{l}\text { MARINE } \\
\text { REF }^{\mathrm{b}}\end{array}$ & E SHELLSa & SAMPLE \# & $\begin{array}{l}\text { HISTORICAL } \\
\text { AGE } \\
(\text { cal AD) }\end{array}$ & $\begin{array}{l}\text { CONVENTIONAL } \\
\text { SAMPLE } 1{ }^{14} \mathrm{C} \text { AGE } \\
\left({ }^{14} \mathrm{C} \text { YRS BP }\right)^{\mathrm{e}}\end{array}$ & $\left({ }^{\left.14_{C} \text { Y YRS BP }\right)^{\mathrm{f}}}\right.$ \\
\hline 11,9 & $\begin{array}{l}\text { Diabasvika, Lagoya, } \\
\text { Spitsbergen } \\
80^{\circ} 34^{\prime} \mathrm{N} 18^{\circ} 35^{\prime} \mathrm{E}\end{array}$ & U-121 & $1958 \mathrm{~g}$ & $670 \pm 80$ & $180 \pm 80^{\mathrm{h}}$ \\
\hline 11,9 & $\begin{array}{l}\text { NE side of Nordre, Russoya, } \\
\text { Murchisonfjorden, Spitsbergen } \\
80^{\circ} 0^{\prime} \mathrm{N} 18^{\circ} 9^{\prime} \mathrm{E}\end{array}$ & $\mathrm{U}-122$ & 19588 & $430 \pm 80$ & $-60 \pm 80^{\mathrm{h}}$ \\
\hline 10 & $\begin{array}{l}\text { Magdalenafj., Spitsbergen } \\
79^{\circ} 34^{\prime} \mathrm{N} 10^{\circ} 40^{\prime} \mathrm{E}\end{array}$ & T- 1541 & 1878 & $632 \pm 70$ & $141 \pm 70$ \\
\hline 11,9 & $\begin{array}{l}\text { Tangen, Mushamna, } \\
\text { Spitsbergen } \\
79^{\circ} 30^{\prime} \mathrm{N} 14^{\circ} \mathrm{E}\end{array}$ & U-133 & $1952 \mathrm{~g}$ & $530 \pm 70$ & $40 \pm 60^{\mathrm{h}}$ \\
\hline 10 & $\begin{array}{l}\text { Adventbukta, Spitsbergen } \\
78^{\circ} 15^{\prime} \mathrm{N} 15^{\circ} 36^{\prime} \mathrm{E}\end{array}$ & $T-1540$ & 1878 & $622 \pm 70$ & $131 \pm 70$ \\
\hline 10 & $\begin{array}{l}\text { Isforden, Spitsbergen } \\
78^{\circ} 07^{\prime} \mathrm{N} 14^{\circ} 08^{\prime} \mathrm{E}\end{array}$ & T-1539 & 1925 & $519 \pm 50$ & $45 \pm 50$ \\
\hline 10 & $\begin{array}{l}\text { Bellsund, Spitsbergen } \\
\mathrm{ca} .77^{\circ} 40^{\prime} \mathrm{N} 14-16^{\circ} \mathrm{E}\end{array}$ & $\mathrm{T}-1538$ & 1926 & $549 \pm 50$ & $75 \pm 50$ \\
\hline 10 & $\begin{array}{l}\text { Near Bear Island } \\
74^{\circ} 07^{\prime} \mathrm{N} 19^{\circ} 04^{\prime} \mathrm{E}\end{array}$ & T-1537 & 1900 & $523 \pm 50$ & $46 \pm 50$ \\
\hline & \multicolumn{3}{|c|}{$\begin{array}{l}\text { WEIGHTED MEAN OF ABOVE } 8 \text { SAMPLES } \\
\text { SCATTER } \sigma \text { IN UNWEIGHTED MEAN IS } 25 \text { YR }\end{array}$} & & $70 \pm 20$ \\
\hline 10 & $\begin{array}{l}\text { Rice Strait, Smith Sound, } \\
\text { Ellesmere Island } \\
78^{\circ} 45^{\prime} \mathrm{N} 74^{\circ} 55^{\prime} \mathrm{E}\end{array}$ & T-1544 & 1898 & $744 \pm 70$ & $266 \pm 70$ \\
\hline 10 & $\begin{array}{l}\text { Goose Bay, Jones Sound, } \\
\text { Ellesmere Island } \\
\text { ca. } 76^{\circ} 45^{\prime} \mathrm{N} 89^{\circ} 00^{\prime} \mathrm{E}\end{array}$ & T-1543 & 1900 & $893 \pm 70$ & $416 \pm 70$ \\
\hline 10 & $\begin{array}{l}\text { Havnef jorden, Jones Sound, } \\
\text { E11esmere Island } \\
76^{\circ} 30^{\prime} \mathrm{N} 84^{\circ} 30^{\prime} \mathrm{E}\end{array}$ & T-1542 & 1899 & $774 \pm 70$ & $297 \pm 70$ \\
\hline & $\begin{array}{l}\text { WEIGHTED MEAN OF ABOVE } 3 \text { SAMPLI } \\
\text { SCATTER } \sigma \text { IN UNWEIGHTED MEAN I }\end{array}$ & LES & & & $325 \pm 40$ \\
\hline 8 & $\begin{array}{l}\mathrm{S} \text { of } \mathrm{L} \text {. Pendulumoen and SE } \\
\text { of Claveringoen, NE Greenland } \\
74^{\circ} 35^{\prime} \mathrm{N} 18^{\circ} 23^{\prime} \mathrm{W} \text { and } \\
74^{\circ} 10^{\prime} \mathrm{N} 20^{\circ} 08^{\prime} \mathrm{W}\end{array}$ & Lu- 650 & 1899 & $591 \pm 38$ & $114 \pm 38$ \\
\hline 8 & $\begin{array}{l}\text { Mackenziebugt, NE Greenland } \\
73^{\circ} 28^{\prime} \mathrm{N} 21^{\circ} 30^{\prime} \mathrm{W}\end{array}$ & Lu-609 & 1900 & $650 \pm 47$ & $173 \pm 47$ \\
\hline 8 & Mackenziebugt, NE Greenland & Lu- 610 & 1900 & $620 \pm 54$ & $143 \pm 54$ \\
\hline
\end{tabular}


TABLE 1 (continued)
MARINE SHELLS ${ }^{a}$

REF NE Greenland

$70^{\circ} 50^{\prime} \mathrm{N} 22^{\circ} 33^{\prime} \mathrm{W}$

S cove, Nyhavn, NE Greenland Y-606

WEIGHTED MEAN OF ABOVE 5 SAMPLES

SCATTER $\sigma$ IN UNWEIGHTED MEAN IS 20 YR

10 Tanafjord, Finnark, N Norway T-1535 $70^{\circ} 30^{\prime}-71^{\circ} \mathrm{N}$ ca. $28^{\circ} 30^{\prime} \mathrm{E}$ Komagfjord, Finnmark,

$\mathrm{T}-958$

N Norway

$70^{\circ} 16^{\prime} \mathrm{N} 23^{\circ} 24^{\prime} \mathrm{E}$

10 Vadso, Finnmark, N Norway T-1536

$70^{\circ} 04^{\prime} \mathrm{N} 29^{\circ} 45^{\prime}$

Tromso, Troms, N Norway T- 1534

WEIGHTED MEAN OF ABOVE 4 SAMPLES

SCATTER $\sigma$ IN UNWEIGHTED MEAN IS 10 YR

Faxa Bay, Kollafjord, Iceland L-576C Kollafjord, Iceland $\mathrm{L}-576 \mathrm{H}$ $64^{\circ} \mathrm{N} 22^{\circ} \mathrm{W}$

Faxa Bay, Kollafjord, Iceland L-576I

HISTORICAL CONVENTIONAL

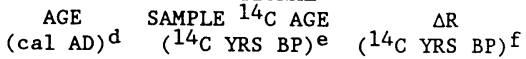

1899

$641+39$

$164 \pm 39$

1957

$550 \pm 70$

$60 \pm 70^{\mathrm{h}}$

$140 \pm 20$

1876

$584 \pm 70$

$91 \pm 70$

1922

$548 \pm 75$

$75 \pm 75$

1857

1857

$543 \pm 50$

$41 \pm 50$

$553 \pm 50$

$51 \pm 50$

1946

$543+51$

$60 \pm 30$

1900

$631+51$

$56 \pm 51$

1840

$154 \pm 51$

WEIGHTED MEAN OF ABOVE 3 SAMPLES

SCATTER $\sigma$ IN UNWEIGHTED MEAN IS 45 YR

9 Fjaerlandsfjorden, Sogn, T-953 (1)

Btwn $61^{\circ} 13^{\prime} \mathrm{N} 6^{\circ} 34^{\prime}$

Teikanger, Sognefjord,

T- 951

$61^{\circ} 11^{\prime} \mathrm{N} 6^{\circ} 48^{\prime} \mathrm{E}$

Vangsnes, Sognefjord, Norway T-952

North Sea, approx. half way T-95 btwn Bergen and Shetland

$60^{\circ} 38^{\prime} \mathrm{N} 22^{\circ} 35^{\prime} \mathrm{E}$
1909

1912

1920

1906

1906
$715 \pm 51$

$-$

$203 \pm 51$

$140 \pm 30$

$541+8$

$438 \pm 75$

$500 \pm 75$

$494 \pm 75$

$469 \pm 50$

$-4+50$
8 Fame Oer, Scoresby Sund,

$61^{\circ} 10^{\prime} \mathrm{N} 6^{\circ} 39^{\prime} \mathrm{E}$

Vikingbank, North Sea
$60^{\circ} 38^{\prime} \mathrm{N} 2^{\circ} 35^{\prime} \mathrm{E}$
MARINE SHELLS ${ }^{a}$

REF $\mathrm{b}$ REGIONC

9 Ideosen, Herdla, Hordaland,

Norway

$60^{\circ} 34^{\prime} \mathrm{N} 5^{\circ} 00^{\prime} \mathrm{E}$

Sollesnes, Jonda1, Hardanger, T-955

Norway $60^{\circ} 18^{\prime} \mathrm{N} 6^{\circ} 17^{\prime} \mathrm{E}$

Mosterhavn, Hordaland, T-956

Norway
$59^{\circ} 42^{\prime} \mathrm{N} 5^{\circ} 24^{\prime} \mathrm{E}$

WEIGHTED MEAN OF ABOVE 8 SAMPLES

SCATTER $\sigma$ IN UNWEIGHTED MEAN IS 15 YR

Brevikfjord, Telemark, Norway T-959

$59^{\circ} 03^{\prime} \mathrm{N} 9^{\circ} 42^{\prime} \mathrm{E}$

Gronholmsund, Risor, Aust-

T- 960

Agder, Norway
$58^{\circ} 44^{\prime} \mathrm{N} 9^{\circ} 18^{\prime} \mathrm{E}$

Near Kristingeberg, island Lu-237

of Skaftolandet, Bohuslan,

$58^{\circ} 15^{\prime} \mathrm{N} 11^{\circ} 26^{\prime} \mathrm{E}$

Bohuslan, Sweden

Haron, Bohuslan, Sweden

Roro, $\mathrm{N}$ archipelago of

Lu- 236

Lu-235

$57^{\circ} 47^{\prime} \mathrm{N} 11^{\circ} 37^{\prime} \mathrm{E}$

Roro, $\mathrm{N}$ archipelago of

Lu- 234

Goteborg, Sweden
$57^{\circ} 47^{\prime} \mathrm{N} 11^{\circ} 37^{\prime} \mathrm{E}$

Skagerak, Norway
$57^{\circ} 44^{\prime} \mathrm{N} 90^{\circ} 53^{\prime} \mathrm{E}$

T-1532

WEIGHTED MEAN OF ABOVE 8 SAMPLES

SCATTER $\sigma$ IN UNWEIGHTED MEAN IS 25 YR

14 Pavlov Harbor, Alaska, USA USGS-234

PI

VALUE USED ON MAP FOR ABOVE SAMPLE

14 Orcas Is., Washington, USA USGS-177 $48.6^{\circ} \mathrm{N}\left(123^{\circ} \mathrm{W}\right)$

4 Orcas Is., Washington, USA USGS-190
HISTORICAL CONVENTIONAL

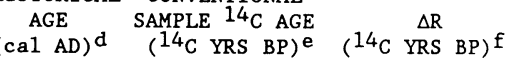

1923

$457 \pm 60$

$-16 \pm 60$

1908

$532+75$

$61 \pm 75$

1918

$402 \pm 90$

$-70 \pm 90$

$5+25$

$1898 \quad 602+80 \quad 124 \pm 80$

$1905 \quad 385 \pm 75 \quad-88 \pm 75$

$1896 \pm 88 \quad 420 \pm 50 \quad-59 \pm 50$

ca.1935 $\quad 510+80 \quad 31 \pm 80$

$1935 \pm 15 \quad 430 \pm 46 \quad-49 \pm 46$

$1930 \pm 10 \quad 410 \pm 46 \quad-65 \pm 46$

$1930 \pm 10 \quad 370 \pm 57 \quad-105 \pm 57$

$1906 \quad 459+50 \quad-14 \pm 50$

$-40 \pm 20$

$700 \pm 50$

$219+50$

$220 \pm 50$ 
TABLE 1 (continued)

\begin{tabular}{|c|c|c|c|c|c|}
\hline $\begin{array}{l}\text { MARIN } \\
\text { REF }^{\mathrm{b}}\end{array}$ & E SHELLS ${ }^{a}$ & SAMPLE \# & $\begin{array}{l}\text { HISTORICAL } \\
\text { AGE } \\
\text { (cal AD) }^{\mathrm{d}}\end{array}$ & $\begin{array}{l}\text { CONVENTIONAL } \\
\text { SAMPLE 14 C AGE } \\
(14 \mathrm{C} \text { YRS BP })^{\mathrm{e}}\end{array}$ & 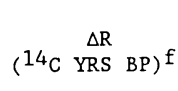 \\
\hline 14 & $\begin{array}{l}\text { Sooke, British Columbia, } \\
\text { Canada } \\
48.4^{\circ} \mathrm{N}\left(124^{\circ} \mathrm{W}\right)\end{array}$ & USGS - 170 & 1916 & $850 \pm 50$ & $378 \pm 50$ \\
\hline 14 & $\begin{array}{l}\text { Esquimalt, British Columbia } \\
\text { Canada } \\
48.3^{\circ} \mathrm{N}\left(123^{\circ} \mathrm{W}\right)\end{array}$ & USGS - 133 & 1930 & $750 \pm 50$ & $275 \pm 50$ \\
\hline 14 & $\begin{array}{l}\text { Yaquina Bay, Oregon, USA } \\
44.6^{\circ} \mathrm{N}\left(124^{\circ} \mathrm{W}\right)\end{array}$ & USGS-169 & 1916 & $840 \pm 35$ & $368 \pm 35$ \\
\hline 14 & $\begin{array}{l}\text { Yaquina Bay, Oregon, USA } \\
44.6^{\circ} \mathrm{N}\left(124^{\circ} \mathrm{W}\right)\end{array}$ & USGS-189 & 1916 & $835 \pm 50$ & $363 \pm 50$ \\
\hline \multirow[t]{2}{*}{14} & $\begin{array}{l}\text { Sunset Bay, Oregon, USA } \\
43.3^{\circ} \mathrm{N}\left(124^{\circ} \mathrm{W}\right)\end{array}$ & USGS - 233 & 1936 & $895 \pm 50$ & $415 \pm 50$ \\
\hline & $\begin{array}{l}\text { WEIGHTED MEAN OF ABOVE } 7 \text { SAMP } \\
\text { SCATTER } \sigma \text { IN UNWEIGHTED MEAN }\end{array}$ & $\begin{array}{l}\text { IPLES } \\
\text { IS } 25 \mathrm{YR}\end{array}$ & & & $390 \pm 15$ \\
\hline \multirow[t]{2}{*}{3} & $\begin{array}{l}\text { Bay of Arcachon, France } \\
44^{\circ} 35^{\prime} \mathrm{N} 1^{\circ} 25^{\prime} \mathrm{W}\end{array}$ & L-599A & 1952 & $846 \pm 42$ & $-4 \pm 42^{h}$ \\
\hline & VALUE USED ON MAP FOR ABOVE S & SAMPLE & & & $-5 \pm 40$ \\
\hline \multirow[t]{2}{*}{2,3} & $\begin{array}{l}\text { Port Jefferson area, Long } \\
\text { Is land Sound, New York, USA } \\
40^{\circ} 57^{\prime} \mathrm{N} 73^{\circ} 05^{\prime} \mathrm{W}\end{array}$ & L-317A & 1954 & $407 \pm 75$ & $-83 \pm 75^{\mathrm{h}}$ \\
\hline & VALUE USED ON MAP FOR ABOVE & SAMPLE & & & $-85+75$ \\
\hline 14 & $\begin{array}{l}\text { Bolinas Bay, California, } \\
\text { USA } \\
37.9^{\circ} \mathrm{N}\left(123^{\circ} \mathrm{W}\right)\end{array}$ & USGS - 248 & $1915 \pm 5$ & $680 \pm 25$ & $209 \pm 25$ \\
\hline 14 & $\begin{array}{l}\text { Half Moon Bay, California, } \\
\text { USA } \\
37.5^{\circ} \mathrm{N}\left(122^{\circ} \mathrm{W}\right)\end{array}$ & USGS - 280 & $1915 \pm 5$ & $745 \pm 35$ & $274 \pm 35$ \\
\hline 14 & $\begin{array}{l}\text { Monterey, California, USA } \\
36.6^{\circ} \mathrm{N}\left(122^{\circ} \mathrm{W}\right)\end{array}$ & USGS-178 & $1915 \pm 5$ & $740 \pm 35$ & $269 \pm 35$ \\
\hline 1 & $\begin{array}{l}\text { Monterey, California, USA } \\
\left(37^{\circ} \mathrm{N} 122^{\circ} \mathrm{W}\right)\end{array}$ & UCLA- 149 & 1878 & $566 \pm 55$ & $75 \pm 55$ \\
\hline 14 & $\begin{array}{l}\text { Morro Bay, California, USA } \\
35.4^{\circ} \mathrm{N}\left(121^{\circ} \mathrm{W}\right)\end{array}$ & USGS - 281 & 1947 & $750 \pm 35$ & $262 \pm 35$ \\
\hline 1 & $\begin{array}{l}\text { Seal Beach, California, } \\
\text { USA } \\
\left(34^{\circ} \mathrm{N} 119^{\circ} \mathrm{W}\right)\end{array}$ & $\begin{array}{l}\text { UCLA- } \\
1033\end{array}$ & 1921 & $553 \pm 48$ & $80 \pm 48$ \\
\hline 14 & $\begin{array}{l}\text { San Diego, California, USA } \\
32.7^{\circ} \mathrm{N}\left(117^{\circ} \mathrm{W}\right)\end{array}$ & USGS -430 & $1915 \pm 5$ & $735 \pm 35$ & $264 \pm 35$ \\
\hline & $\begin{array}{l}\text { WEIGHTED MEAN OF ABOVE } 7 \text { SAM } \\
\text { SCATTER } \sigma \text { IN UNWEIGHTED MEAN }\end{array}$ & MPLES & & & $225 \pm 15$ \\
\hline
\end{tabular}

TABLE 1 (continued)

MARINE SHELLSa

REF REGIONC $^{\mathrm{C}}$

2,3 Kouali Point, Tipasa, Algeria
$36^{\circ} 40^{\prime} \mathrm{N} 20^{\circ} 30^{\prime} \mathrm{E}$

VALUE USED ON MAP FOR ABOVE SAMPLE

Kino Bay, Sonora, Mexico UCLA-914
$\left(29^{\circ} \mathrm{N} 112^{\circ} \mathrm{W}\right)$

Carmen Is., Gulf of California,
$\left(26^{\circ} \mathrm{N} 111^{\circ} \mathrm{W}\right)$

WEIGHTED MEAN OF ABOVE 2 SAMPLES SCATTER $\sigma$ IN UNTEIGHTED MEAN IS 10 YR

\section{Cedro Is., Baja California, UCLA-963} Mexico

$\left(28^{\circ} \mathrm{N} 115^{\circ} \mathrm{W}\right)$

1 Magdaleno Bay, Baja UCLA-939 California, Mexico

$\left(25^{\circ} \mathrm{N} 112^{\circ} \mathrm{W}\right)$

Cape San Lucas, Baj $\left(23^{\circ} \mathrm{N} 110^{\circ} \mathrm{W}\right)$

$1 \quad$ Mazatlan, Si

Isabel Island, Nayarit,

UCLA- 936

Mexico

Banderas Bay, Jalisco, UCLA-940

$\left(21^{\circ} \mathrm{N} 105^{\circ} \mathrm{W}\right)$

1 Manzanillo, Colima, Mexico UCLA-915

$\left(19^{\circ} \mathrm{N} 104^{\circ} \mathrm{W}\right)$

Guatulco Bay, Oaxaca, UCLA-938

Mexico

WEIGHTED MEAN OF ABOVE 8 SAMPLES

SCATTER $\sigma$ IN UNWEIGHTED MEAN IS 20 YR

HISTORICAL CONVENTIONAL

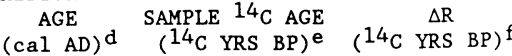

$357 \pm 83$

$-133 \pm 83^{h}$

SCATTER $\sigma$ IN UNWEIGHTED MEAN IS 20

Bahama Islands

L-576B

Bahama Islands
1950

$1885 \pm 5$

$-135 \pm 85$

$514 \pm 53$

$531 \pm 54$

$520+40$

1939

$614 \pm 51$

$132 \pm 51$

1938

$660 \pm 53$

$179+53$

$784 \pm 45$

$307 \pm 45$

1939

$662 \pm 48$

$180+48$

$207 \pm 50$

1938

$688 \pm 5$

$606 \pm 50$

$125+50$

1930

$675 \pm 50$

$200 \pm 50$

$140 \pm 50$

$185+15$

$428 \pm 42 \quad-62 \pm 42$

$525 \pm 59 \quad 39+59$ 
TABLE 1 (continued)

\section{MARINE SHELLS ${ }^{a}$}

REF ${ }^{b}$

The Rocks, offshore of Florida Keys, USA

Jamaica, B.W.I.

$18^{\circ} \mathrm{N} 78^{\circ} \mathrm{W}$

Jamaica, ${ }^{\mathrm{B}}$
$18^{\circ} \mathrm{N} 78^{\circ} \mathrm{W}$

WEIGHTED MEAN OF ABOVE 5 SAMPLES
SCATTER $\sigma$ IN UNWEIGHTED MEAN IS 20 YR

Oahu, Hawaii, USA

L-576J

HISTOR

AGE CONVENTIONAL

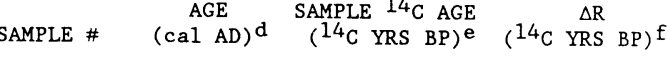

(annual "1850"

coral

(1800-1900)

L-576A

1929-1930

1884

VALUE USED ON MAP FOR ABOVE SAMPLE

Off Bogan Island, Eniwetok

$11^{\circ} 30^{\prime} \mathrm{N} 162^{\circ} 10^{\prime} \mathrm{E}$

L-584A
(cora1)

VALUE USED ON MAP FOR ABOVE SAMPLE

Port Parker, Costa Rica (ca. $10^{\circ} \mathrm{N} 85^{\circ} \mathrm{W}$ ) Secas Island, Panama Secas Island,

Secana

UCLA- 1254

UCLA-1256A

UCLA-1256B

Santiago Is., Galapagos Is. UCLA-1255A 1934

Santiago Is., Galapagos Is. UCLA-1255A 1934

Santiago Is.,

UCLA-1255B 1934

UCLA-1255C 1934

$\left(0^{\circ} \mathrm{N} 90^{\circ} \mathrm{W}\right)$ US

Santa Cruz

$\left(0^{\circ} \mathrm{N} 90^{\circ} \mathrm{W}\right)$

Guayaquil, Ecuador

(ca. $3^{\circ} \mathrm{S} 80^{\circ} \mathrm{W}$ )

Guayaquil, Ecuador

UCLA-1249A 1927

UCLA-1249B 1927

WEIGHTED MEAN OF ABOVE 9 SAMPLES

SCATTER $\sigma$ IN UNWEIGHTED MEAN IS 50 YR
$-240 \pm 37$

$61 \pm 45$

$5 \pm 15$

TABLE 1 (continued)

$518+16$

$423+42$

$13 \pm 16$

$425+41$

$-52+42$

$-62 \pm 41$

$-5 \pm 15$

MARINE SHELLSa

REF

REGION ${ }^{\mathrm{C}}$

Northern Peru

(ca. $10^{\circ} \mathrm{S} 80^{\circ} \mathrm{W}$ )

(ca. $14^{\circ} \mathrm{S} 78^{\circ} \mathrm{W}$ )

Antofagasta, Chile

Valparaiso

$\left(33^{\circ} \mathrm{S} 72^{\circ} \mathrm{W}\right) \mathrm{Ch}$

WEIGHIED MEAN OF ABOVE 3 SAMPLES (WITH

SCATTER $\sigma$ IN UNWEIGHTED MEAN IS 40 YR

$117 \pm 51$

$115+50$

$142+43$

$629+43$

$140+45$

$695+37 \quad 216+37$

$403+51$

$-76 \pm 51$

$507+49$

$28+49$

$538+53$

$60 \pm 53$

$745+82$

$267 \pm 82$

$468+43$

$-10+43$

$443 \pm 40$

$-34+40$

$235 \pm 37$

$536 \pm 45$
Torres Strait, Australian SUA-354/1

ca. $10^{\circ} \mathrm{S} 143^{\circ} \mathrm{E}$

Torres Strait, Australian

ca. $10^{\circ} \mathrm{S} 143^{\circ} \mathrm{E}$

Torres Strait, Australian SUA-357

$32^{\circ} 15^{\prime} \mathrm{S} 115^{\circ} 40^{\prime}$,

$32^{\circ} 15^{\prime} \mathrm{S} 115^{\circ} 40^{\prime} \mathrm{E}$. Australia SUA-355

ca. $35^{\circ} \mathrm{S} 139^{\circ} \mathrm{E}$

$36^{\circ} 13^{\prime} \mathrm{S}$ 150 $150^{\circ} 07^{\prime} \mathrm{E}$

WEIGHTED MEAN OF ABOVE 6 SAYPLES

SCATTER $\sigma$ IN UNWEIGHTED MEAN IS 25 YR

Tahiti
$18^{\circ} \mathrm{S} 149^{\circ} \mathrm{W}$

L-576E

Moorea $18^{\circ} \mathrm{S} 149^{\circ} \mathrm{W}$

L- $576 \mathrm{~K}$

WEIGHTED MEAN OF ABOVE 2 SAMPLES

SCATTER $\sigma$ IN UNWEIGHTED MEAN IS $20 \mathrm{yr}$

New Zealand

...-

New Zealand

New Zealand

Otago, New Zealand

(ca. $45^{\circ} \mathrm{S} 170^{\circ} \mathrm{E}$ ) $\cdots$

-..-

INS no.
1957

$1883 \pm 3$

$553+42$

HISTORICAL CONVENTIONAL

\begin{tabular}{ccc} 
AGE & SAMPLE ${ }^{14} \mathrm{C}$ AGE & \multicolumn{2}{c}{$\Delta R$} \\
$(14 \mathrm{C} \text { YRS BP })^{\mathrm{e}}$ & $\left({ }^{14} \mathrm{C} \text { YRS BP }\right)^{\mathrm{f}}$
\end{tabular}

$1935 \pm 5 \quad 700 \pm 49 \quad 221 \pm 49$

$1935 \pm 5 \quad 1127 \pm 44 \quad 648 \pm 44$

$1925 \quad 626 \pm 34 \quad 152 \pm 34$

$1935 \pm 5 \quad 770 \pm 76$

$291 \pm 76$

$190+25$

$-13+67$

$-30 \pm 84$

$-67 \pm 84$

$-21+84$

$102 \pm 85$

$-10 \pm 84$

$-5+35$

$25 \pm 42^{\mathrm{h}}$

$65+42$

$45+30$

$1923 \quad 416+42 \quad-57+42$

$1925 \quad 371 \pm 50 \quad-103 \pm 50$

$1949 \quad 210+41 \quad-280 \pm 41$

$1955 \quad 446 \pm 42 \quad-44 \pm 42^{\mathrm{h}}$ 
TABLE 1 (continued)

MARINE SHELLS ${ }^{a}$

$\mathrm{REF}^{\mathrm{b}}$

REGION ${ }^{\mathrm{c}}$
HISTORICAL CONVENTIONAL

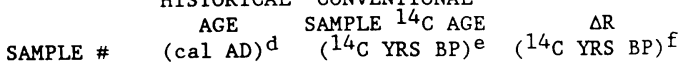

WEIGHTED MEAN OF ABOVE 3 SAMPLES (WITH $-280 \pm 41$ EXCLUDED) SCATTER O IN UNWEIGHTED MEAN IS 20 YR

15 Inexpressible Island, Antarctica

QL-171

1912

$1390 \pm 40$

(ca. $74^{\circ} 54^{\prime} \mathrm{s}$

Inexpressible Island

QL-173

1912

$1300 \pm 50$ (ca. 74'54'S $163^{\circ} 39^{\prime} \mathrm{E}$ )

WEIGHTED MEAN OF ABOVE 2 SAMPLES

SCATTER $\sigma$ OF UNWEIGHTED MEAN IS 45 YR a Exceptions are marked.

b References are: (1) Berger et a1., 1966; (2) Broecker and 01son, 1959; (3) Broecker and Olson, 1961; (4) Druffel and Linick, 1978; (5) Gillespie and Polach, 1979; (6) Hakansson, 1969; (7) Hakannson, 1970; (8) Hakansson, 1973; (9) Mangerud, 1972; (10) Mangerud and Gulliksen, 1975; (11) 01sson, 1960; (12) Olsson et al., 1969; (13) Rafter et al (16) Taylor and Berger, 1967; and (17) Washburn and Stuiver, 1962

c Our own estimates of missing coordinates are in parentheses.

d Age refers to calendar year of death. Only pre-1959 samples are listed.

e Conventional radiocarbon age is: taken directly from original listing (references 14,15 , and 17); assumed equivalent to reported "apparent age" (references 6 and 7); calculated from reported $\delta^{14} \mathrm{C}$ or $\Delta^{14} \mathrm{C}$ (references 1,13 , and 16); calculated from reported $\Delta^{14}$ C after removal of age correction (references $4,5,8,9$, and 12); calculated from reported $\Delta{ }^{14} \mathrm{C}$ after removal of age correction to 1958 (references and 3$)$; or calculated from reported $\Delta^{14} \mathrm{C}$ after removal of age correction and fossil fuel correction (reference 10 and Rafter valu

f Sigma in $\Delta R\left(\sigma_{R}\right)$ is minimum error based on reported error in conventional sample ${ }^{14} \mathrm{C}$ age.

$g$ Exact year of death is not known.

$\mathrm{h}$ Computation is based on the model mixed layer radiocarbon age calculated for AD 1950 